\title{
Episodic vertical nutrient fluxes and nearshore phytoplankton blooms in Southern California
}

\author{
M. M. Omand,1,* F. Feddersen, R. T. Guza, and P. J. S. Franks \\ Scripps Institution of Oceanography, La Jolla, California
}

\begin{abstract}
Three distinct phytoplankton blooms lasting 4-9 d were observed in approximately 15-m water depth near Huntington Beach, California, between June and October of 2006. Each bloom was preceded by a vertical $\mathrm{NO}_{3}$ flux event 6-10 d earlier. $\mathrm{NO}_{3}$ concentrations were estimated using a temperature proxy that was verified by comparison with the limited $\mathrm{NO}_{3}$ observations. The lower-water-column vertical $\mathrm{NO}_{3}$ flux from vertical advection was inferred from observed vertical isotherm displacement. Turbulent vertical eddy diffusivity was parameterized based on the observed background $\left(<0.3\right.$ cycles $\left.\mathrm{h}^{-1}\right)$ stratification and vertical shear in the horizontal currents. The first vertical nitrate flux event in June contained both advective and turbulent fluxes, whereas the later two events were primarily turbulent, driven by shear in the lower part of the water column. The correlation between the $\mathrm{NO}_{3}$ flux and the observed chlorophyll $a(\mathrm{Chl} a)$ was maximum $\left(r^{2}=0.40\right)$ with an 8 -d lag. A simple nitrate-phytoplankton model using a linear uptake function and driven with the $\mathrm{NO}_{3}$ flux captured the timing, magnitude, and duration of the three $\mathrm{Chl} a$ blooms (skill $=0.61$ ) using optimal net growth rate parameters that were within the expected range. Vertical and horizontal advection of Chl $a$ past the measurement site were too small to explain the observed $\mathrm{Chl} a$ increases during the blooms. The vertical $\mathrm{NO}_{3}$ flux was a primary control on the growth events, and estimation of both the advective (upwelled) and turbulent fluxes is necessary to best predict these episodic blooms.
\end{abstract}

In the Southern California Bight, the seasonal phytoplankton cycle generally begins with a large spring bloom, followed by a series of episodic blooms during the rest of the year (Kim et al. 2009). Dense blooms observed in the nearshore (depth $<20 \mathrm{~m}$ ) may last only a few days, and are challenging to monitor and predict (Anderson 1997; Horner et al. 1997). Harmful algal blooms (HABs) may produce adverse effects such as toxins, fish gill damage, or anoxia (Smayda 1997; Anderson et al. 2008), and HABs that occur in the nearshore are particularly damaging because of the high exposure to coastal and benthic habitats. An understanding of the drivers of these nearshore $\mathrm{HABs}$ and red tides is critical for improved management of aquaculture industries and other coastal resources (Anderson 1997).

The drivers of nearshore chlorophyll $a(\mathrm{Chl} a)$ variability in southern California are not well understood. For example, in a 20 -yr record of Chl $a$ from the Scripps pier in La Jolla, California ( 4-m water depth), there is no correlation between monthly averaged nearshore Chl $a$ and temperature, wind, or climate indices (Kim et al. 2009). Monthly averaged (Kim et al. 2009) and intraseasonal (Legaard and Thomas 2007) nearshore Chl $a$ are up to $10 \times$ more variable than offshore. This variability may be enhanced through allochthonous terrestrial nutrient delivery from rainfall and groundwater (Santoro et al. 2010) or through autochthonous episodic vertical nutrient fluxes, which is the focus of this paper.

\section{*Corresponding author: momand@whoi.edu}

${ }^{1}$ Present address: Woods Hole Oceanographic Institution, Woods Hole, Massachusetts
Autotrophic phytoplankton growth is restricted to a euphotic depth $\left(\mathrm{Z}_{e u}\right)$ below which there is insufficient light for net photosynthesis. In exceptionally clear water, $z_{e u}$ may reach 400-m depth, whereas in the often turbid and productive southern California nearshore, $\mathrm{z}_{e u}$ may be only 15-20 m deep (Holmes 1970). Nitrate is consumed rapidly above $\mathrm{z}_{e u}$, limiting productivity. In general, $\mathrm{NO}_{3}$ is undetectable from the surface down to a sharp gradient, denoted the nitracline. The nitracline is maintained by a balance between $\mathrm{NO}_{3}$ uptake within the euphotic zone and vertical flux and remineralization or oxidation from below, and is stable with the density (in the Southern California Bight, temperature $T$ ) structure of the water column over time periods longer than phytoplankton uptake and growth timescales (Cullen et al. 1983).

The upward vertical flux of nitrate into the euphotic zone, widely believed to be a critical control on phytoplankton growth (Eppley et al. 1979), may be advective or turbulent. Advective $\mathrm{NO}_{3}$ flux occurs if the nitraclinefollowing the isopycnals - is raised above $\mathrm{z}_{e u}$ by mechanisms such as upwelling (Huyer 1983; Denman and Powell 1984; Traganza et al. 1987), coastally trapped waves (CTWs; Chavez 1996), or the internal tide (Lucas et al. 2011). Turbulent vertical $\mathrm{NO}_{3}$ fluxes may be generated by internal-wave (IW) breaking (Sharples et al. 2001; Noble et al. 2009), or vertical shear in the surface layer and bottom boundary layer (BBL) (Souza and Pineda 2001). In the nearshore, the euphotic zone, the BBL, and the region of IW breaking often overlap. To make direct turbulent flux estimates requires highly temporally and spatially resolved measurements (Dewey and Crawford 1987). However, parameterizations that use bulk averages of currents, shear, and stratification are useful in estimating dissipation or vertical diffusivity when (as in the present case) highly 


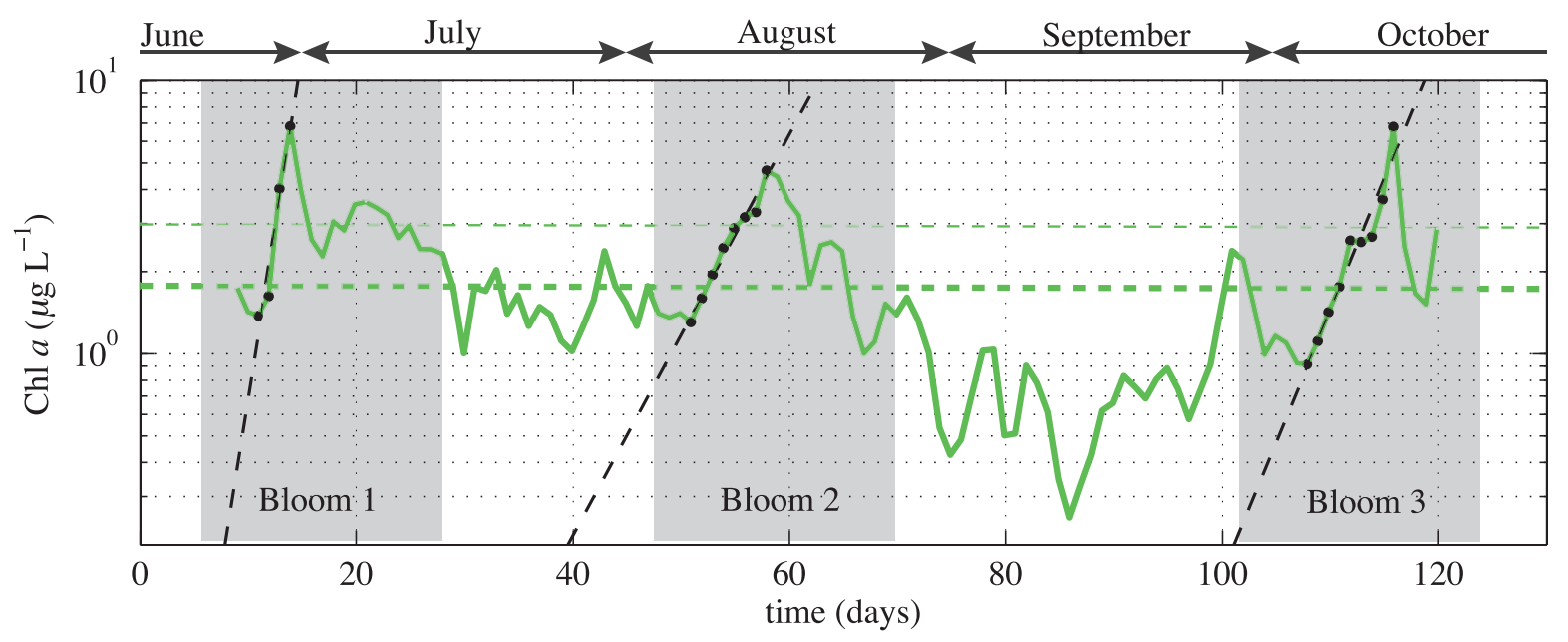

Fig. 1. 24-h averaged time series of $\mathrm{Chl} a(\mu \mathrm{g} \mathrm{L}-1$, solid green line) measured at $\sim 15-\mathrm{m}$ depth during the summer and fall of 2006 at Huntington Beach, California. Three bloom events are identified, which initially show sustained exponential increases (dashed black lines) over 4, 8, and $9 \mathrm{~d}$ respectively (black dots), and each surpasses 1.5 standard deviations (thin dashed green line) from the mean Chl $a$ (thick dashed green line). Intensive bloom sampling was conducted during bloom 3 between 27 September (day 100) and 16 October (day 120).

resolved measurements are unavailable (Mackinnon and Gregg 2005).

Here, three distinct phytoplankton blooms, one of which was a red tide of the dinoflagellate Lingulodinium polyedrum, were observed with a Chl $a$ fluorometer between mid-June and mid-October 2006, in 15-m water depth near Huntington Beach, California (day $1=$ June 18; Fig. 1). To examine the role of the $\mathrm{NO}_{3}$ flux in the phytoplankton blooms, we estimated the vertical advective and turbulent nitrate fluxes in 18-m water depth during this 4-month period. We used temperature as a proxy for $\mathrm{NO}_{3}$, and, using water column measurements of currents and temperature, inferred the episodic advective and turbulent $\mathrm{NO}_{3}$ fluxes. We found that a $\mathrm{NO}_{3}$ flux event preceded each bloom event, suggesting that the blooms were a response to these fluxes. This hypothesis was tested using a lagged correlation analysis between $\mathrm{Chl} a$ and the vertical flux, and also with a nitrate-phytoplankton (NP) model. We chose a very simple model formulation, and explored the output over a range of phytoplankton growth and loss parameters. Other sources of variability in the measured Chl $a$ time series were investigated and some recommendations for improved monitoring and prediction of red tide events discussed.

\section{Methods}

Nearshore and shelf observations were made at Huntington Beach, California, for 4 months between 18 June and 25 October 2006. Data are presented from a subset of moorings, and from a shorter small-boat-based sampling program (between 27 September and 16 October). Observations spanned $0.5 \mathrm{~km}$ alongshore $(y)$ and $4 \mathrm{~km}$ offshore (x) to 25-m depth (Fig. 2). The mean (tidally averaged) water depth is $H$, and the vertical coordinate $z$ is positive upward, with $z=0 \mathrm{~m}$ at the tidally averaged surface.

Moored observations-A cross-shore transect of moorings, paired with bottom or surface-mounted current meters spanning $H=8-59 \mathrm{~m}$, was deployed (Omand et al. 2011). Data from a subset of these instruments are discussed here. Moorings in $H=8$ and $18 \mathrm{~m}$ (M8 and M18 in Fig. 2) were instrumented with four (M8) and five (M18) Star-Oddi ( $T$ only, www.star-oddi.com/) or Sea Bird MicroCAT ( $C$ and $T$, www.seabird.com) instruments sampling at 3-min intervals (blue circles, Fig. 2). Crossshore $(u)$ and alongshore $(v)$ currents near M18 were measured with a bottom-mounted Acoustic Doppler Current Profiler (ADCP, $600 \mathrm{kHz}$, www.rdinstruments. com) from June to October (Wong et al. 2012). The ADCP data were averaged to 6-min intervals with 1-m vertical bins. A bottom-mounted Nortek Aquadopp at M8 (2000 kHz, www.nortekusa.com) sampled every $2.5 \mathrm{~min}$ with $0.5-\mathrm{m}$ vertical bins.

At mooring M15, a Chl a fluorometer (WET Labs, www.wetlabs.com) was deployed at $z=-14 \mathrm{~m}$ between 28 June and 17 September (green circle at M15, Fig. 2). The Chl $a$ data were sampled at $0.25 \mathrm{~Hz}$ and averaged to 6-min intervals. A wirewalker, a wave-driven vertically profiling platform (Rainville and Pinkel 2001), was deployed at $H=$ $13 \mathrm{~m}$ (green line at M13 in Fig. 2b) between 17 September and 18 October. The wirewalker was instrumented with a conductivity, temperature, and depth profiler (CTD) (Seabird 49, sample rate $16 \mathrm{~Hz}$ ) and a $\mathrm{Chl} a$ fluorometer (WET Labs ECO Triplet, sample rate $16 \mathrm{~Hz}$ ). Vertical CTD + Chl $a$ wirewalker profiles at M13 were completed approximately every $2 \mathrm{~min}$; data were averaged into $0.1-\mathrm{m}$ vertical bins and interpolated onto regular 4-min intervals. The M13 wirewalker was intermittently nonoperational, with data gaps up to $4 \mathrm{~h}$.

Nonphotochemical quenching corrections of Chl $a$ fluorescence measurements were derived from continuous profiles of Chl $a$ at M13 and surface irradiance (measured with a Davis Vantage Pro Plus cosine pyranometer), and applied to all in situ Chl $a$ measurements (Omand et al. 2011). The maximum near-bottom Chl $a$ correction at both M15 and M13 was less than 5\% during peak daylight 

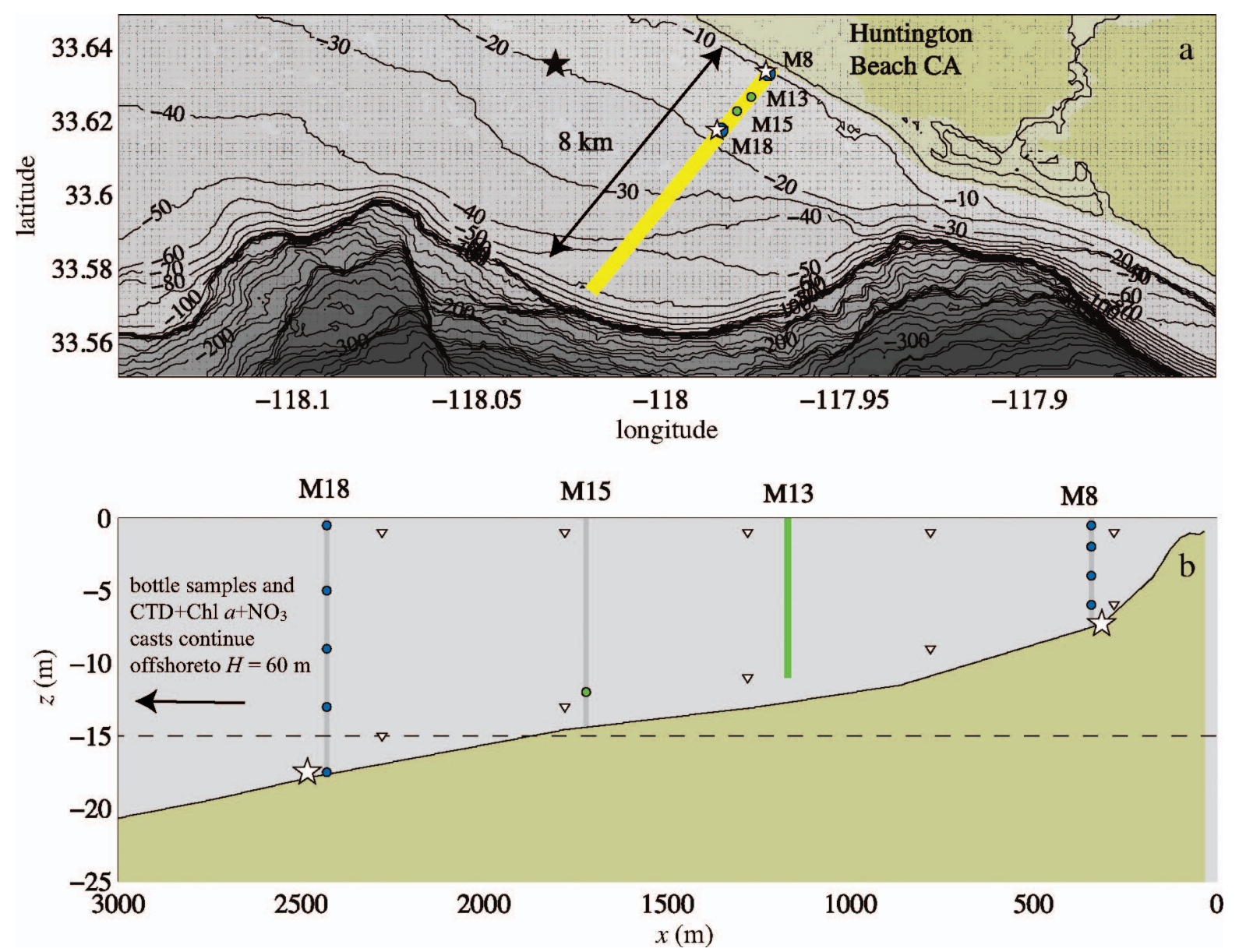

Fig. 2. Instrument schematic: (a) plan view of bathymetry contours, and (b) cross-shore transect of bathymetry on the nearshore ( $H$ $<20 \mathrm{~m}$ ) instrument transect line. The vertical coordinate $z=0 \mathrm{~m}$ is at the tidally averaged surface and positive upward, the cross-shore $(x)$ coordinate is positive offshore, and $y$ is positive to the southeast. Moored thermistor strings (blue circles, M8 and M18) were located at tidally averaged depths $H=8$ and $18 \mathrm{~m}$. A vertically profiling CTD + Chl $a$ wirewalker (green line, M13) was located at $H=13 \mathrm{~m}$. A Chl $a$ fluorometer was located near bottom at $H=15 \mathrm{~m}$. Bottom-mounted ADCPs (stars) were located near moorings M8 and M18 (Wong et al. 2012). Boat-based CTD $+\mathrm{Chl} a+\mathrm{NO}_{3}$ profiles (yellow line) and water samples (open triangles) spanned the shelf to $H=$ $60 \mathrm{~m}$.

hours. The M13 fluorometer was calibrated using extracted Chl $a$ from adjacent water samples collected throughout the M13 deployment to within a $13 \%$ uncertainty $\left(\mathrm{n}=18, r^{2}=\right.$ 0.79 , with a scale factor of $\left.16.8 \pm 2.2 \mu \mathrm{g} \mathrm{L}^{-1} \mathrm{~V}^{-1}\right)$. Similarly, comparison of the Wetlabs fluorometer at M15 with the fluorometer at M13 and nearby water samples indicated that M15 was within $20 \%$ of the provided factory calibration. Calibration drift was not obvious over the 1 month of water sample collections. The M15 Chl $a$ time series from $z=-14 \mathrm{~m}$ and the lowest 2-m portion of the wirewalker $\mathrm{Chl} a$ time series were merged and averaged to 24-h intervals resulting in a single 4-month-long nearshore Chl $a$ time series (Fig. 1).

Choice of the euphotic depth $\mathrm{z}_{\mathrm{eu}}$-The vertical nitrate flux was calculated through the base of the euphotic zone, $z_{e u}$. The $z_{e u}$ depth depends on the water column diffuse attenuation of irradiance, which was not measured in situ at HB06. Instead, the sensitivity of the results to a range of $z_{e u}$ at M18 was explored, between -16 and $-12 \mathrm{~m}$ (10 m was the shallowest euphotic depth observed with a Secchi disk in $H \approx 18 \mathrm{~m}$ at Imperial Beach, California). The magnitude of the estimated $\mathrm{NO}_{3}$ varied by $40 \%$ over this range, but the temporal variability in $\mathrm{NO}_{3}$ remained the same. Results using $z_{e u}=-14 \mathrm{~m}$ will be presented here.

Intensive small-boat-based sampling-Densely spaced vertical profiles and bottle samples were collected during the final month of the 4-month-long program. Cross-shore transects of CTD (Seabird 19), optical nitrate (Satlantic ISUS V3, www.satlantic.com) and flow-through $\mathrm{Chl} a$ fluorometer (WET Labs WETStar) profiles spanning $6 \mathrm{~km}$ cross-shore (from $H=40 \mathrm{~m}$ to $H=5 \mathrm{~m}$ ) were conducted between 9:00 $\mathrm{h}$ and 11:30 $\mathrm{h}$ once per day on 27 September and 01, 04, 05, 07, 08, 12, and 16 October. CTD + Chl $a+$ $\mathrm{NO}_{3}$ data were post-processed with Seabird Electronics standard filters and averaged to 1-m-depth bins. The top $5 \mathrm{~m}$ of optical nitrate data were noisy, and excluded from the analysis. A total of 131 water samples were collected near the bottom with a messenger-tripped Niskin bottle 


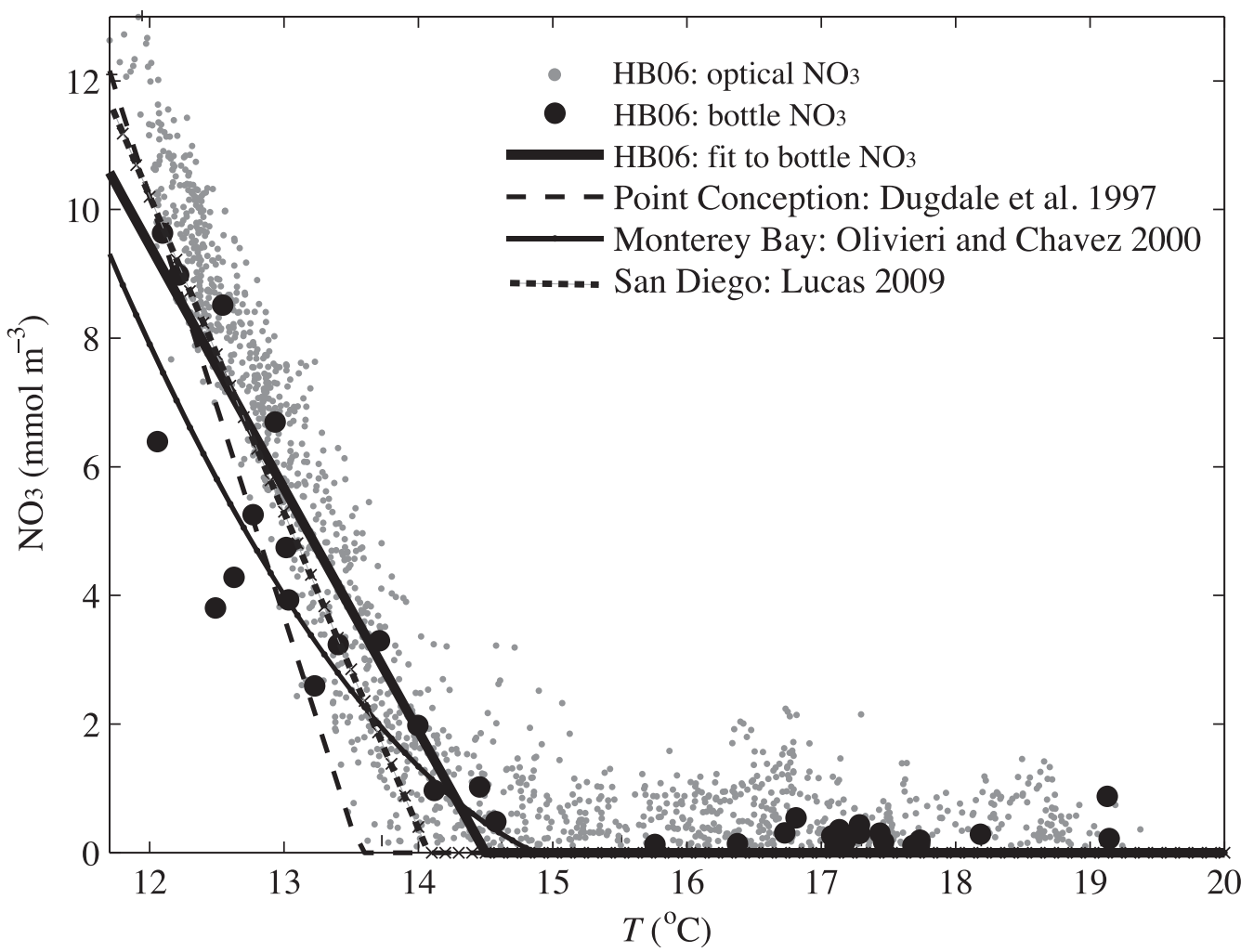

Fig. 3. Optical (gray points) and bottle (black circles) $\mathrm{NO}_{3}$ measurements vs. temperature $(T)$, and the linear fit (thick black curve) to the $\mathrm{NO}_{3}$ bottle data vs. temperature at HB06 throughout the intensive bloom-sampling period. The HB06 fit is consistent with previous fits to observations from throughout the Southern California Bight (Dugdale et al. 1997; Olivieri and Chavez 2000; Lucas 2009).

mounted $1 \mathrm{~m}$ above the CTD, and at the surface by hand during most CTD + Chl $a+\mathrm{NO} 3$ casts (triangles, Fig. 2b). Onboard, water samples were kept dark and on ice. Ashore, triplicate water samples of $150 \mathrm{~mL}$ were filtered (Whatman $\mathrm{GF} / \mathrm{F}$ ), analyzed for Chl $a$, and frozen for subsequent analysis of dissolved inorganic nitrate, phosphate, ammonium, and silicate concentrations using a QuikChem 8000 flow injection analyzer. The in situ sampling was used to verify or calibrate the Chl $a$ and $\mathrm{NO}_{3}$ from the optical instruments. In addition, 82 of the water samples were preserved for phytoplankton taxonomic identification by transferring $100 \mathrm{~mL}$ of seawater to a glass Wheaton bottle and combining it with $10 \mathrm{~mL}$ buffered $37 \%$ formaldehyde. The preserved samples were analyzed with the Utermöhl settling method (Utermöhl 1958) and inspected at $160 \times$ magnification using a light microscope. All visible cells $(>5 \mu \mathrm{m})$ were enumerated and identified to a genus or species level when possible. Omand et al. (2011) describes this intensive study period in detail.

\section{Results}

The $\mathrm{NO}_{3}$-temperature relationship - Salinity effects on density were always small, and the density $(\rho)$ was strongly controlled by $T$. In the Southern California Bight, there is a consistent and long-term stable (decades) relationship between $\mathrm{NO}_{3}$ and $T$ (Cullen et al. 1983; Dugdale et al. 1997; Olivieri and Chavez 2000; Lucas 2009; Parnell et al.
2010). Below the nitracline the $\mathrm{NO}_{3}-T$ relationship is roughly linear. Coincident temperature and $\mathrm{NO}_{3}$ measurements (optical profiles and bottle samples) were collected during October at the $\mathrm{HB} 06$ field location. Optical $\mathrm{NO}_{3}$ decreased with increasing $T$ until $14.5^{\circ} \mathrm{C}$, where $\mathrm{NO}_{3}$ approached zero (Fig. 3). This $\mathrm{NO}_{3}-T$ relationship was independent of the day and cross-shore location and is consistent with observations at Huntington Beach from July of that summer (Wong et al. 2012) and prior observations from the Southern California Bight (Fig. 3). A temperature-based nitrate proxy, denoted as $\mathrm{NO}_{3, T}$ (bold line in Fig. 3), is developed from a linear best fit between bottle sampled $\mathrm{NO}_{3}$ and $T$ below $T=14.5^{\circ} \mathrm{C}$, as

$$
\begin{aligned}
& \mathrm{NO}_{3, T}= \\
& \begin{cases}3.8\left(\mathrm{mmol} \mathrm{m}^{-3}{ }^{\circ} \mathrm{C}^{-1}\right) T+54.8 \mathrm{mmol} \mathrm{m}^{-3} & \text { for } T \leq 14.5^{\circ} \mathrm{C} \\
0 & \text { for } T>14.5^{\circ} \mathrm{C}\end{cases}
\end{aligned}
$$

allowing $\mathrm{NO}_{3}$ to be estimated based on observed temperature.

Moored observations at M18 - Over the 4-month M18 record, $T$ generally ranged between $15^{\circ} \mathrm{C}$ and $20^{\circ} \mathrm{C}$, with most variability at subtidal and tidal scales (Fig. 4a). Cool water $\left(\leq 15^{\circ} \mathrm{C}\right)$ appeared episodically for durations of 5$20 \mathrm{~d}$. For example, a strong cooling event occurred between days 5 and 15 , centered at day 10 , where near-bottom $T$ dropped below $10^{\circ} \mathrm{C}$. Stratification $\left(N^{2}\right)$ was calculated 
from the first difference of the low-pass-filtered $T$ (with a filter cutoff at $\omega=0.3$ cycles $\mathrm{h}^{-1}$ ) at each of the five thermistors spanning the water column at M18, and $N^{2}$ varied between 0 and $0.003 \mathrm{~s}^{-2}$. Stratification was strong over the summer between days 1 and 70 (mid-June to September; Fig. 4b) with a maximum stratification consistent with a sharp, mid-column thermocline. A BBL (defined where $\Delta \rho=0.2 \mathrm{~kg} \mathrm{~m}^{-3}$ from density interpolated to the seafloor) occasionally spanned $50 \%$ of the water column, rarely reaching the surface (black contour, Fig. 4b).

The temperature-based $\mathrm{NO}_{3, T}$ was typically low $\left(<0.5 \mathrm{mmol} \mathrm{m} \mathrm{m}^{-3}\right.$, Fig. $\left.4 \mathrm{c}\right)$, except during the strong cooling event centered at day 10 , when $\mathrm{NO}_{3, T}$ reached $13 \mathrm{mmol} \mathrm{m} \mathrm{m}^{-3}$. Similarly, the vertical nitrate gradient $\left(\partial \mathrm{NO}_{3, T} / \partial z\right)$ was usually low, ranging between 0 and $0.5 \mathrm{mmol} \mathrm{m}^{-4}$, with elevated values concentrated near the seafloor, except during the cooling event centered at day 10 , when $\partial \mathrm{NO}_{3, T} / \partial z$ reached $2 \mathrm{mmol} \mathrm{m}{ }^{-4}$ near the $14.5^{\circ} \mathrm{C}$ isotherm in $z \geq-10 \mathrm{~m}$ (Fig. 4d).

The vertical velocity $w=\mathrm{d} z_{\text {iso }} / \mathrm{d} t$ was estimated from the vertical displacements $\left(z_{\text {iso }}\right)$ of the isotherms at each depth. Temperature was interpolated between sensors to $10-\mathrm{cm}$ intervals and then the displacement of each isotherm was obtained between consecutive 6-min intervals. The vertical displacement rate of the isotherms was then averaged over $24 \mathrm{~h}$, to exclude vertical advection due to the internal tide and high-frequency IWs. The estimated $w$ varied between $\pm 5 \times 10^{-5} \mathrm{~m} \mathrm{~s}^{-1}$ (Fig. 4e). As anticipated, upward advection (warm colors in Fig. 4e) began the cooling events and downward advection (cool colors in Fig. 4e) ended them.

The horizontal current variability was dominated by subtidal alongshelf currents that were strongest at the surface and decreased towards the seafloor. The remainder (roughly 15\%) of the current variability was mainly due to baroclinic mode 1 tidal variability. The horizontal current speed $|u|=\left(u^{2}+v^{2}\right)^{-1 / 2}$ varied between 0 and $0.6 \mathrm{~m} \mathrm{~s}^{-1}$ (Fig. 4f). The squared total vertical shear $\left(S^{2}=(\partial u / \partial z)^{2}+\right.$ $\left.(\partial v / \partial z)^{2}\right)$ was estimated from the low-pass-filtered currents with cutoff at 7.2 cycles per day (cpd). The sum of the first two empirical orthogonal functions (EOFs, corresponding to $90 \%$ of the total variance) of $S^{2}$ (following Mackinnon and Gregg 2003) varied between near 0 and $0.002 \mathrm{~s}^{-2}$ (Fig. 4g). The 5-15-d periods of enhanced shear centered at days 17,60 , and 110 corresponded with periods of enhanced near-surface current speed. The maximum shear however, occurred subsurface, either at mid-column (as would be anticipated for baroclinic modes; see days 53-68) or near the bottom (as would be anticipated for a logarithmic BBL; see days 17, 29, 117). The fluctuation of shear maxima between mid-column (low-mode baroclinic IWs) and near-bottom (boundary layer mixing) suggests that turbulent vertical nitrate flux can be driven by either process.

Vertical turbulent $\mathrm{NO}_{3}$ flux-The vertical turbulent nitrate flux $\mathrm{FNO}_{3}^{\text {(turb) }}$ across $z_{e u}$ is

$$
F_{\mathrm{NO}_{3}}^{(\mathrm{turb})}=-\left.\kappa \frac{\partial \mathrm{NO}_{3, T}}{\partial z}\right|_{z=z_{e u}}
$$

where $\kappa$ is the local vertical eddy diffusivity and $\partial \mathrm{NO}_{3, T} / \partial z$ was estimated from the temperature-derived $\mathrm{NO}_{3, T}$ (Fig. 4d) at $z_{e u}$. The euphotic depth $z_{e u}=-14 \mathrm{~m}$ is sometimes above and other times within the BBL (black contour, Fig. 4b), also suggesting flux contributions from both shear-induced BBL mixing and mid-column IW mixing. Here, the IW- and BBL-induced diffusivities were investigated separately and compared. Mixing from wind (Csanady 1984) and white-capping wave breaking (Agrawal et al. 1992) was neglected because winds were weak, the mid-column stratification was strong, and $z_{e u}$ was closer to the seabed than the sea surface.

\section{BBL parameterized vertical diffusivity}

Within the BBL, turbulent shear stress $\tau=\rho u^{* 2}$, where $u^{*}$ is the friction velocity, is roughly constant. The logarithmic BBL vertical eddy diffusivity is $\kappa_{\mathrm{BBL}}$ :

$$
\kappa_{B B L}=k u * z_{b}
$$

where $k=0.41$ is Von Karman's constant and $z_{b}$ is the height above the bed. A constant stress layer and Eq. 2 result in the classic BBL logarithmic velocity profile (Tennekes and Lumley 1972)

$$
|u|=\frac{u *}{k} \log \left(\frac{z_{b}}{z_{b 0}}\right)
$$

where $z_{b 0}$, the "apparent" bed roughness, is the height where $|u|=0$, which in combined wave-current flows can be a function of the currents, waves, and bed roughness (Grant and Madsen 1979). Estimates of $u^{*}$ every $2 \mathrm{~h}$ were derived from fits of the lowest four ADCP velocity bins (spanning $z_{b}$ $=2-5 \mathrm{~m}$, see Fig. 5) to $\log \left(z_{b}\right)$. Subtidally filtered (33-h cutoff) currents were used in the logarithmic fits, as it is over these longer time scales that the log BBL profiles develop. For the fits, $z_{b 0}$ was set to $1 \mathrm{~cm}$, appropriate for the muddy bottom at M18 (Grant et al. 1984). The resulting $u^{*}$ ranged between 0.05 and $0.9 \mathrm{~cm} \mathrm{~s}^{-1}$ (black line, Fig. 6a) similar to the $u^{*}$ range of $0.5-1 \mathrm{~cm} \mathrm{~s}^{-1}$ found by Grant et al. (1984), on a muddy bottom over the same $|u|$ range. The velocity profiles were usually consistent with a logarithmic profile with (least-squares) fit skill $>0.9$ (Fig. 6b).

These estimates of $u^{*}$ assume weak stratification that does not limit the eddy vertical length scale. Thus, when stratification is stronger, $u^{*}$ (and therefore $\kappa_{\mathrm{BBL}}$ ) is overestimated. Friction velocity $u^{*}$ can also be derived from a quadratic drag law, i.e.,

$$
u^{*}=C_{d}|u|^{2}
$$

where $C_{d}$ is a drag coefficient. On the New England shelf in $70 \mathrm{~m}$ water depth, direct stress observations indicated that at a height $1.1 \mathrm{~m}$ above the bed, $\mathrm{C}_{d}=1.5 \times 10^{-3}$ (Shaw 1999). The $u^{*}$ estimated with Eq. 4 at $z_{b}=2 \mathrm{~m}$ using $C_{d}=1.5 \times 10^{-3}$ were consistent with the $\log$-fit $u^{*}$ (compare gray and black curves in Fig. 6a), suggesting that both stress estimates are reasonable. The $\kappa_{\mathrm{BBL}}$ was then estimated at the base of the euphotic zone from Eq. 2 using the $\log$-fit $u^{*}$ and $z_{b}=H+z_{e u}=4 \mathrm{~m}$. 

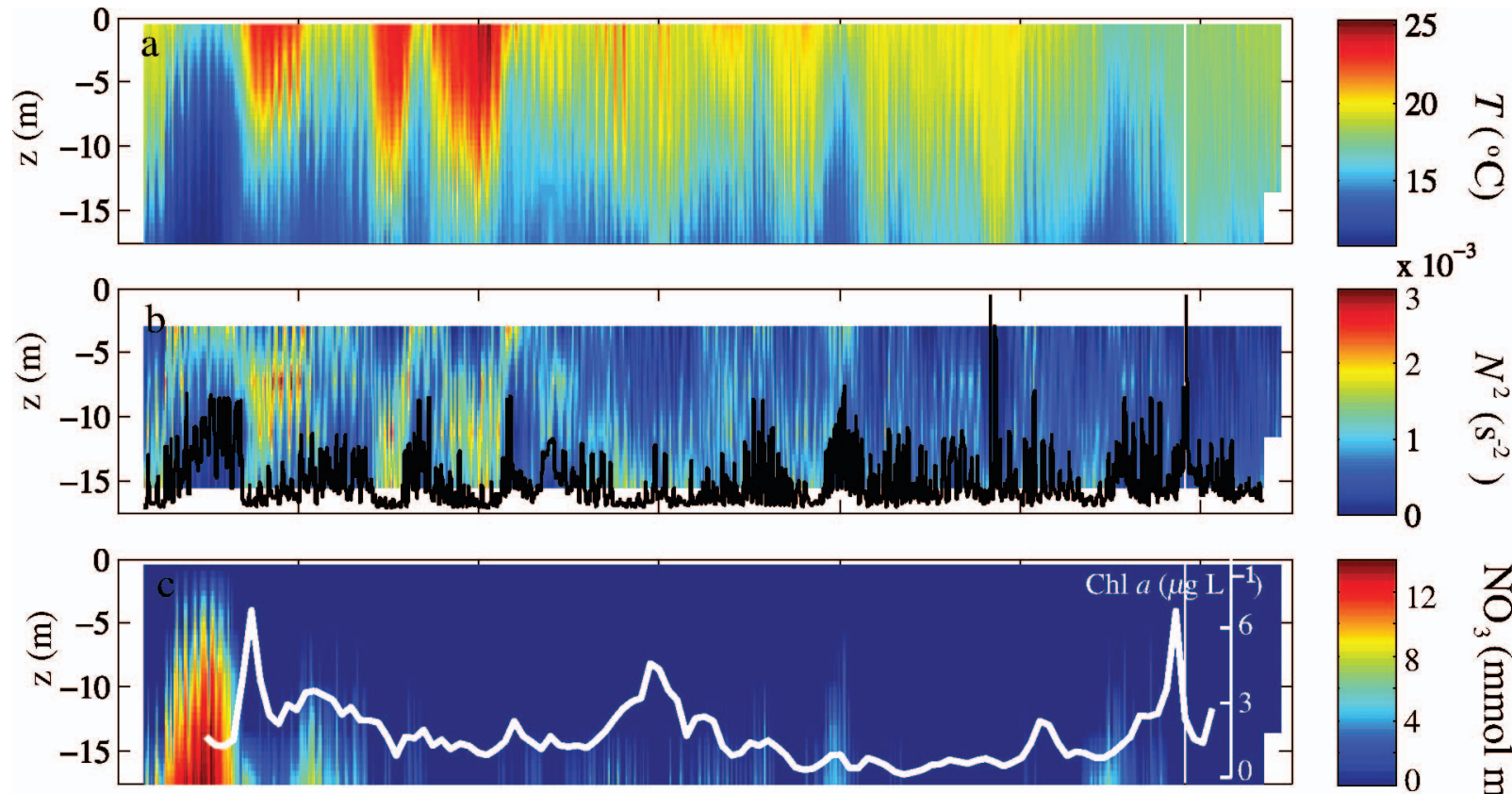

宐
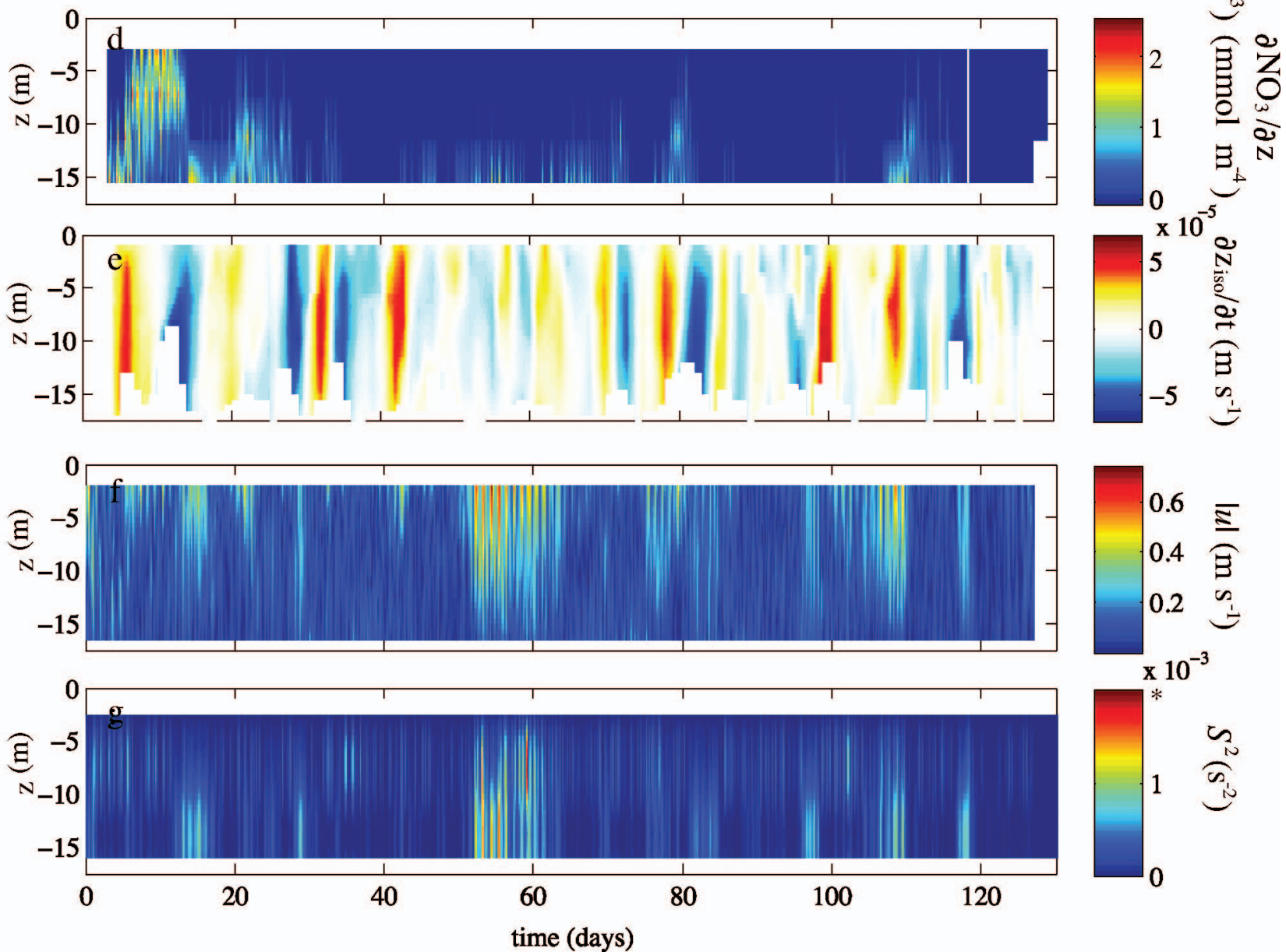

$\times 10^{-3}$

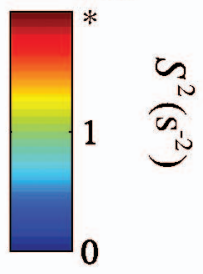

Fig. 4. Time series at mooring M18 of (a) temperature $T\left({ }^{\circ} \mathrm{C}\right)$, (b) buoyancy frequency squared $N^{2}\left(\mathrm{~s}^{-2}\right)$ where the black contour indicates an approximate BBL width given by a density difference $(\Delta \rho)$ from the bottom of $0.2 \mathrm{~kg} \mathrm{~m}^{-3}$, (c) nitrate proxy (from $T$, $\mathrm{mmol} \mathrm{m}{ }^{-3}$ ) with 24-h-averaged $\mathrm{Chl} a$ superimposed to demonstrate the time variability (white line), (d) vertical nitrate gradient $\partial \mathrm{NO}_{3, T} /$ $\partial \mathrm{z}\left(\mathrm{mmol} \mathrm{m}^{-4}\right)$, (e) isotherm displacement rate $w=\partial z_{\text {iso }} / \partial t\left(\mathrm{~m} \mathrm{~s}^{-1}\right)$, (f) current speed $|u|\left(\mathrm{m} \mathrm{s}^{-1}\right)$, and (g) shear squared $S^{2}\left(\mathrm{~s}^{-2}\right)$. (f,g) The vertical resolution of the currents and shear was $0.5 \mathrm{~m}$, and (a-e) each series derived from $T$ was vertically interpolated onto a $0.5-\mathrm{m}$ grid. 


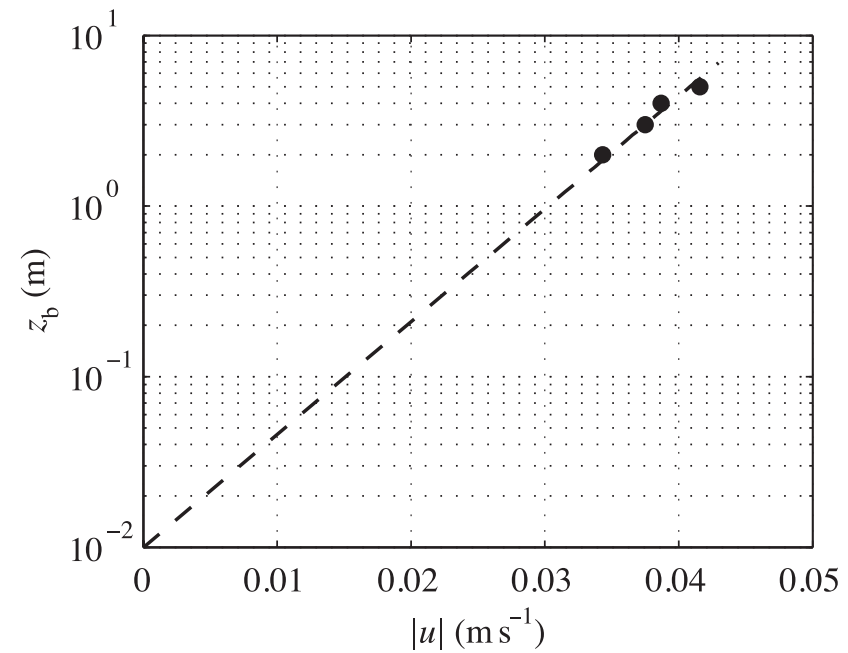

Fig. 5. Height above the bed $z_{\mathrm{b}}$ vs. current magnitude $|u|$ from the four near-bed current meter bins (black dots), and logarithmicfit velocity (dashed line) with $z_{\mathrm{b} 0}$ fixed at $1 \mathrm{~cm}$ (correlation $r^{2}=0.96$ $[p<0.01]$ and skill of 0.99 ) for one 2-h-averaged segment (day $=$ 47.7) of the subtidally filtered currents at M18.

\section{Coastal mid-water column IW breaking diffusivity parameterization}

Most IW-based turbulence parameterizations are based upon the observed spectral properties of open-ocean IW fields (Henyey et al. 1986; Gregg 1989), and are inappropriate for the nearshore where the surface layer and the BBL can intersect and vertical wavenumbers are depth limited. The shear-driven turbulent dissipation rate in subcritical Richardson number $\left(R i=S^{2} / N^{2}\right)$ flows on coastal shelves has been parameterized (Mackinnon and Gregg 2005, hereafter denoted $\varepsilon_{\mathrm{MG}}$ ) as

$$
\varepsilon_{\mathrm{MG}}=\varepsilon_{o} \frac{S}{S_{o}} \frac{N}{N_{o}}
$$

where $S$ and $N$ are the low-mode, low-frequency shear and stratification respectively, and $\varepsilon_{o}, S_{o}$, and $N_{o}$ are reference values selected to match microstructure-derived $\varepsilon$ (Mackinnon and Gregg 2005). Based upon empirical observations of the relationship between shear production and buoyancy flux, the vertical eddy diffusivity $\left(\kappa_{\mathrm{MG}}\right)$ is given by (Osborn 1980; Gargett and Moum 1995)

$$
\kappa_{\mathrm{MG}}=\Gamma \frac{\varepsilon_{\mathrm{MG}}}{N^{2}}
$$

where $\Gamma$ is a mixing efficiency $(\approx 0.2)$. Note that this implies that $\varepsilon_{\mathrm{MG}} \propto S / N$ or $\propto R i^{-1 / 2}$. The low-pass (with cutoff at 0.3 cycles per hour)-filtered shear ( $S$, Fig. $4 \mathrm{f}$ ) and buoyancy frequency $(N$, Fig. $4 d)$ were vertically averaged between $z=-13$ and $-17.5 \mathrm{~m}$ (Fig. 7a). The buoyancy frequency $N$ varied between 0.010 and $0.035 \mathrm{~s}^{-1}$ with a trend towards lower $N$ from summer to fall (black curve in Fig. 7a). The shear $S$ generally varied between 0.005 and $0.02 \mathrm{~s}^{-1}$, except for the 10-d time period centered around day 55 when $S$ increased to between 0.02 and $0.035 \mathrm{~s}^{-1}$ (gray curve in Fig. 7a).
The dissipation $\varepsilon_{\mathrm{MG}}$ was estimated from Eq. 5 with $S_{o}=$ $N_{o}=3 \mathrm{cph}$ and $\varepsilon_{o}=1.1 \times 10^{-9} \mathrm{~W} \mathrm{~kg}^{-1}$ (Fig. 7b). The resulting $\varepsilon_{\mathrm{MG}}$ is more strongly correlated with $S\left(r^{2}=0.82\right.$, $p<0.001)$ than with $N\left(r^{2}=0.17, p<0.001\right)$. The vertical diffusivity $\kappa_{\mathrm{MG}}$ was then estimated using Eq. 6 . Although the New England shelf parameters $\left(\varepsilon_{o}, S_{o}\right.$, and $\left.N_{o}\right)$ may not be appropriate in the shallower waters here, the choice of these constants affects the magnitude of $\varepsilon_{\mathrm{MG}}$, but does not affect the correlation between $\varepsilon_{\mathrm{MG}}$ and $S$.

\section{Comparison of $\kappa$ from BBL and MG parameterizations}

In the nearshore near the euphotic depth, the turbulent vertical $\mathrm{NO}_{3}$ flux was governed by both IW and BBL processes, which cannot be separated with the limited observations available. The $\kappa_{\mathrm{BBL}}$ varied between 0.1 and $1.4\left(\times 10^{-3}\right) \mathrm{m}^{2} \mathrm{~s}^{-1}$ and the $\kappa_{\mathrm{MG}}$ varied between 0.05 and $0.4\left(\times 10^{-3}\right) \mathrm{m}^{2} \mathrm{~s}^{-1}$ (gray and black curves in Fig. 8a). The $\kappa_{\mathrm{MG}}$ and $\kappa_{\mathrm{BBL}}$ estimates are correlated $\left(r^{2}=0.65, p<\right.$ 0.001 ), and differ in magnitude by about a factor of 3 . Both $\kappa$ parameterizations are proportional to the water column shear S. For example, $\kappa_{\mathrm{MG}} \propto S / N$ and is correlated with $S$ $\left(r^{2}=0.72, p<0.001\right)$ and not with $N\left(r^{2}=0.12\right)$, whereas (with some rearrangement) $\kappa_{\mathrm{BBL}}=k^{2} z_{\mathrm{b}}^{2} S$. Thus, $\kappa_{\mathrm{MG}}$ implicitly includes both IW-breaking and BBL mixing processes.

The correct $\kappa$ magnitude is not known accurately for either method. The $\kappa_{\mathrm{MG}}$ scaling used constants of Mackinnon and Gregg (2005), and $\kappa_{\mathrm{BBL}}$ was probably overestimated owing to stratification within the BBL. The $\kappa_{\mathrm{MG}}$ is more consistent than $\kappa_{\mathrm{BBL}}$ with the diffusivity magnitude $0.05-0.5\left(\times 10^{-3} \mathrm{~m}^{2} \mathrm{~s}^{-1}\right)$ estimated by Eppley et al. (1979) in nearshore southern California, and is thus used to estimate the turbulent vertical $\mathrm{NO}_{3}$ flux.

\section{Turbulent vertical $\mathrm{NO}_{3}$ flux}

The vertical turbulent $\mathrm{NO}_{3}$ flux depends on $\partial \mathrm{NO}_{3, T} / \partial z$, the vertical $\mathrm{NO}_{3}$ gradient at $z_{e u}$ (Eq. 1). The (T-derived) subtidally averaged (33-h cutoff) gradient varied between 0 and $1.2 \mathrm{mmol} \mathrm{m}^{-4}$ (red curve in Fig. 8a) and was strongest during days $0-30$, bracketing the early cooling event. The turbulent flux $\mathrm{FNO}_{3}^{\text {(turb) }}$ estimate varied between 0 and $25 \mathrm{mmol} \mathrm{m}^{-2} \mathrm{~d}^{-1}$ and was elevated above $10 \mathrm{mmol} \mathrm{m}^{-2} \mathrm{~d}^{-1}$ near days $1-7,16-26,53-58$, and $108-112$, when both $\kappa_{\mathrm{MG}}$ and $\partial \mathrm{NO}_{3, T} / \partial z$ were elevated (Fig. 8a,b).

Advective vertical $\mathrm{NO}_{3}$ flux - The vertical advective $\mathrm{NO}_{3}$ flux across $z_{e u}$ is

$$
\mathrm{F}_{\mathrm{NO}_{3}}^{(\mathrm{adv})}=\left.w \mathrm{NO}_{3}\right|_{z=z_{e u}}
$$

where $\mathrm{NO}_{3}$ is the nitrate concentration and $w$ the vertical velocity at $z_{e u}$. $\mathrm{NO}_{3, T}$ and $w$ at $z_{e u}$ varied most during the first 40 d (Fig. 8c). After day 40, $\mathrm{NO}_{3}$ at $z_{\text {eu }}$ remained low (s $0.5 \mathrm{mmol} \mathrm{m}^{-3}$ ) until briefly reaching $2 \mathrm{mmol} \mathrm{m}^{-3}$ on days 80 and 109. $\mathrm{FNO}_{3}^{\text {(adv) }}$ (Eq. 7), had similar temporal structure (Fig. 8d), with a large $\mathrm{NO}_{3}$ positive peak (upward $\mathrm{NO}_{3}$ flux) 

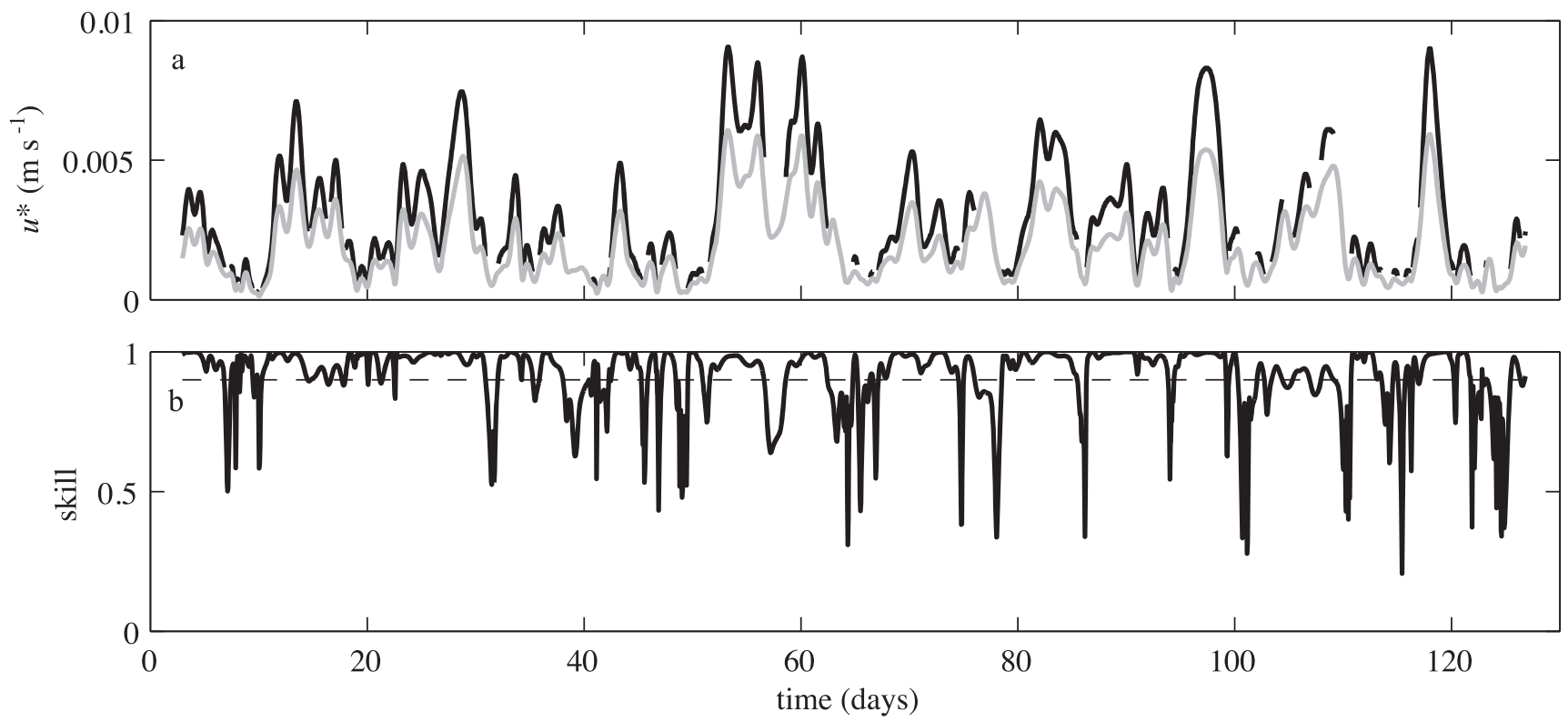

Fig. 6. Time series at mooring M18 of (a) $u^{*}\left(\mathrm{~m} \mathrm{~s}^{-1}\right)$ derived from logarithmic fits (black curve) and from a quadratic drag law (Eq. 4, gray curve) with $C_{d}=1.5 \times 10^{-3}$ (Shaw 1999) and (b) skill of the logarithmic fit (e.g., Fig. 5). In (a), the two estimates of $u^{*}$ are highly correlated $\left(r^{2}=0.99, p<0.001\right)$. In (b), $28 \%$ of the log-fit data had skill that fell below the 0.9 cutoff limit (gray horizontal dashed line) and were removed from the analysis in (a).

centered at day 10 , and smaller positive peaks at days 21 and 108 , each followed by a negative (downward) flux.

Comparison of $\mathrm{FNO}_{3}^{(t u r b)}, \mathrm{FNO}_{3}(\mathrm{adv})$, and $\mathrm{Chl}$ a-The total vertical nitrate flux $\left(\mathrm{FNO}_{3}^{\text {(tot) }}\right)$ is the sum of the 24-h averaged turbulent $\mathrm{FNO}_{3}^{\text {(turb) }}{ }^{3}$ (Fig. 8b) and advective $\mathrm{FNO}_{3}^{(\mathrm{adv})}$ (Fig. 8d) fluxes:

$$
\mathrm{FNO}_{3}^{(\text {tot })}=\mathrm{FNO}_{3}^{(\mathrm{adv})}+\mathrm{FNO}_{3}^{(\mathrm{turb})}
$$

$\mathrm{FNO}_{3}^{(\text {tot })}$ showed a series of distinct pulses during which the flux increased from zero up to $28 \mathrm{mmol} \mathrm{m}^{-2} \mathrm{~d}^{-1}$ (black line, Fig. 8e). The first $\mathrm{FNO}_{3}^{\text {(tot) }}$ event (days 0-20 in Fig. 8e) had a significant contribution from both advection of $\mathrm{NO}_{3}$ and turbulence, whereas the second (days 50-80) and third (days $105-115) \mathrm{FNO}_{3}^{\text {(tot) }}$ events were dominated by the turbulent flux $\mathrm{FNO}_{3}^{\text {(turb) }}$ (Fig. 8b,e). Each bloom (see green arrows in Fig. 8e) was preceded by a $\mathrm{FNO}_{3}^{\text {(tot) }}$ event (see black arrows in Fig. 8e). Chl $a$ was significantly correlated $(p<0.001)$ with $\mathrm{FNO}_{3}^{\text {(tot) }}$ at lags of $6-10 \mathrm{~d}$ after the $\mathrm{FNO}_{3}^{\text {(tot) }}$ events, with a maximum correlation $r^{2}=0.40$ at an 8-d lag, supporting the
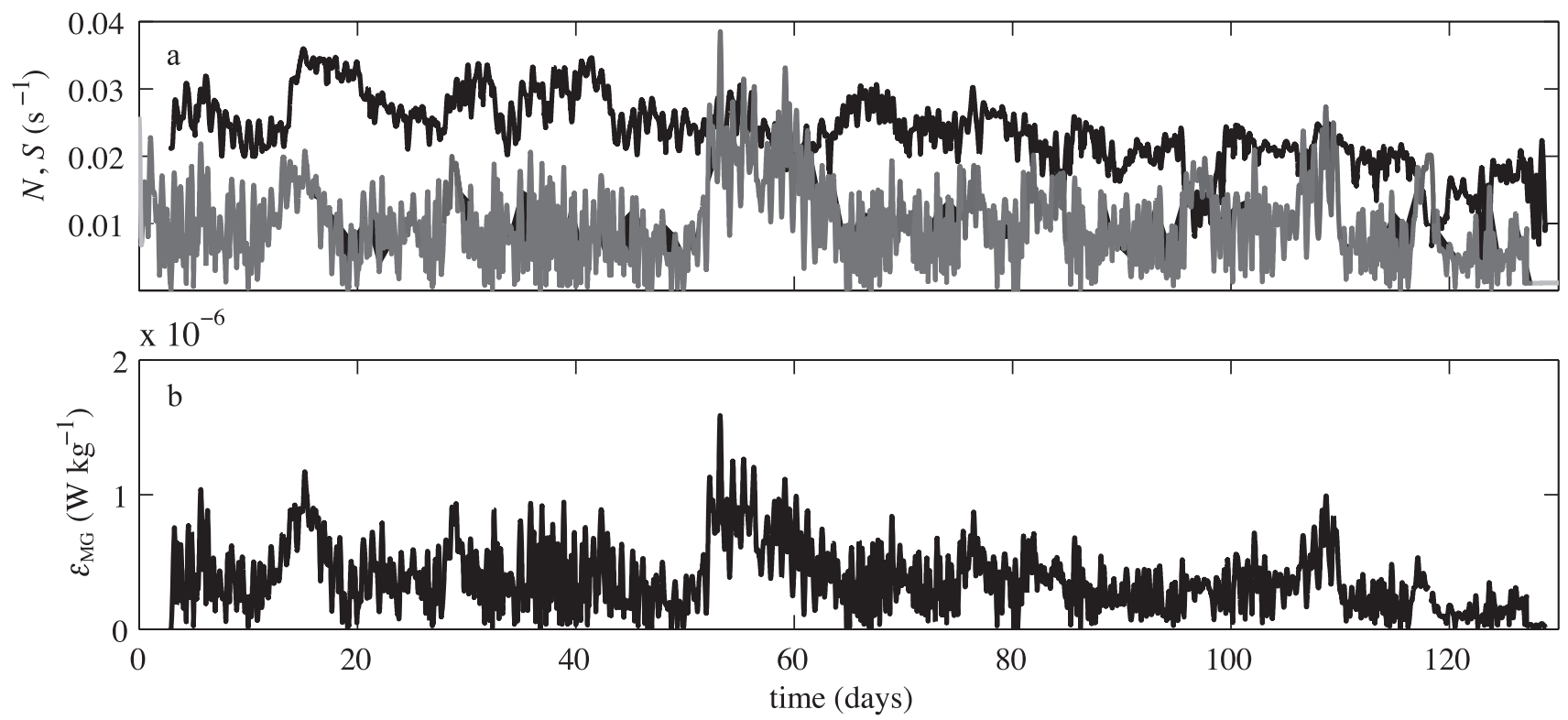

Fig. 7. Time series at M18 of vertically averaged low frequency (a) shear $S$ ( $\mathrm{s}^{-1}$, gray line) and stratification $N$ (s ${ }^{-1}$, black line) across the bottom $5 \mathrm{~m}$ of the water column, and (b) estimated turbulent dissipation rate $\left(\varepsilon_{\mathrm{MG}}\right)$. 
hypothesis that the vertical $\mathrm{NO}_{3}$ flux was an important bloom precursor.

A simple $\mathrm{FNO}_{3}^{(\text {tot })}$-driven NP model-Motivated by the significant lagged correlation between estimated $\mathrm{FNO}_{3}^{(\text {tot })}$ and observed Chl $a$ (Fig. 8), a simple NP box model was used to test whether the estimated nitrate flux could drive the observed Chl $a$ variability and to diagnose the relevant biological rates of growth and mortality. Modeled estimates of the vertically averaged (over the euphotic zone) nitrate $\mathrm{NO}_{3}^{(\mathrm{m})}$ and phytoplankton $P(\mathrm{~m})$ (both with units of $\mathrm{mmol} \mathrm{m} \mathrm{m}^{-3}$ of nitrogen) are

$$
\begin{gathered}
\frac{\mathrm{d} P^{(\mathrm{m})}}{\mathrm{dt}}=(\mu-m) P^{(m)} \\
\frac{\mathrm{dNO}_{3}^{(\mathrm{m})}}{\mathrm{dt}}=-\mu P^{(m)}+\frac{\mathrm{F}_{\mathrm{NO}}^{(\mathrm{tot})}}{\mathrm{Z}_{\mathrm{eu}}}
\end{gathered}
$$

where $m\left(\mathrm{~d}^{-1}\right)$ is the assumed constant phytoplankton loss rate from the euphotic zone, and the growth rate $\mu\left(\mathrm{d}^{-1}\right)$ is a function of the $\mathrm{NO}_{3}$ concentration. $\mathrm{NO}_{3}^{(\mathrm{m})}$ is forced by the estimated vertical $\mathrm{FNO}_{3}^{\text {(tot) }}$, which is assumed to deliver nutrients over the entire euphotic depth $z_{e u}$. The model neglects variations in growth and loss rate and in advection (see Discussion), and has no depth dependence (assumes vertical uniformity above $z_{e u}$ ). The vertical distribution of Chl $a$ was only measured during bloom 3 (Omand et al. 2011), revealing a relatively vertically uniform 24-h averaged $\mathrm{Chl} a$.

Modeled Chl $a^{(\mathrm{m})}$ is related to the modeled phytoplankton $\mathrm{P}^{(\mathrm{m})}$ by Chl $a^{(\mathrm{m})}=\alpha \mathrm{P}(\mathrm{m})$ where $\alpha=2.65 \mathrm{mmol} \mathrm{N}(\mathrm{mg}$ Chl $a)^{-1}$ estimated from the Chl $a$ : nitrogen relationship (Redfield 1958) assuming a carbon to Chl $a$ ratio $\theta=30$ $(\mathrm{mg} \mathrm{C}) /(\mathrm{mg} \mathrm{Chl} a)$, which is a reasonable value for coastal species (Cloern et al. 1995). Similar to the other bulk community variables discussed, $\theta$ may vary among species and depend upon environmental conditions (Behrenfeld et al. 2005). Changing the constant value of $\theta$ scales the $\mathrm{Chl}$ $a^{(\mathrm{m})}$ magnitude linearly and therefore does not affect their correlation.

In NP models, a Monod growth rate $\mu_{\mathrm{M}}$ function is typically used:

$$
\mu_{\mathrm{M}}=\frac{\mu_{\max } \mathrm{NO}_{3}}{K_{\mathrm{s}}+\mathrm{NO}_{3}}
$$

where $\left.K_{\mathrm{s}}(\mathrm{mmol} \mathrm{m})^{-3}\right)$ is a half-saturation constant and $\mu_{\max }\left(\mathrm{d}^{-1}\right)$ is the maximum growth rate. The parameters $\mu_{\max }$ and $K_{\mathrm{s}}$ may be highly variable among phytoplankton groups (Eppley et al. 1969), and span an order of magnitude under similar environmental (i.e., temperature, salinity, depth) conditions (Smayda 1997). A typical range for $\mu_{\max }$ is between 0.5 and $3.5 \mathrm{~d}^{-1}$, and $K_{\mathrm{s}}$ between 0.5 and $8 \mathrm{mmol} \mathrm{m}-3$, with diatoms generally exhibiting a lower $K_{\mathrm{s}}$ than dinoflagellates (Parsons et al. 1978; Smayda 1997).

If $\mathrm{NO}_{3}<K_{\mathrm{s}}$ or if the phytoplankton community is very diverse (representing a spectrum of $\mu_{\max }$ and $K_{\mathrm{s}}$ ), then the Monod growth rate function (Eq. 11) may be simplified (Franks 2009) to a linear uptake function $\left(\mu_{V}\right)$ defined as

$$
\mu_{V}=V \mathrm{NO}_{3}^{(\mathrm{m})}
$$

where $V=\mu_{\max } /\left(2 K_{\mathrm{s}}\right)$ is chosen so that when $\mathrm{NO}_{3}=K_{\mathrm{s}}$, $\mu_{V}=\mu_{\mathrm{M}}$. The nonzero (temperature-based) $\mathrm{NO}_{3, T}$ were less than $K_{\mathrm{s}}=3.4 \mathrm{mmol} \mathrm{m} \mathrm{m}^{-3}$, a nominal $K_{\mathrm{s}}$ for diatoms and dinoflagellates, $89 \%$ of the time (vertical dashed line, Fig. 9). Below this $K_{\mathrm{s}}$ threshold, $\mu_{\mathrm{M}}$ (gray line, Fig. 9) and $\mu_{V}$ (black line, Fig. 9) are similar. The simpler linear uptake function $\mu_{V}$ has an advantage of one fewer parameter over the more complex $\mu_{\mathrm{M}}$, simplifying model investigation and testing.

The NP model was initialized with zero $\mathrm{NO}_{3}^{(\mathrm{m})}$ and nearzero $\mathrm{P}^{(\mathrm{m})}$ on day 1 of the $\mathrm{FNO}_{3}^{\text {(tot) }}$ record and $8 \mathrm{~d}$ prior to the start of the Chl $a$ record. The 24-h averaged observed $\mathrm{FNO}_{3}^{\text {(tot) }}$ was used as a model forcing and the model was run for the 120-d record with 10-min time steps. $\mathrm{NO}_{3}^{(\mathrm{m})}$ and $\mathrm{P}^{(\mathrm{m})}$ were subsequently averaged back into $24-\mathrm{h}$ intervals and $\mathrm{P}^{(\mathrm{m})}$ was converted to $\mathrm{Chl} a^{(\mathrm{m})}$ (i.e., Chl $\left.a^{(\mathrm{m})}=\alpha \mathrm{P}^{(\mathrm{m})}\right)$. The (depth-averaged) model $\mathrm{Chl} a^{(\mathrm{m})}$ is compared to Chl $a^{\text {(obs) }}$ measured at a single depth, assuming that $\mathrm{Chl} a^{(\mathrm{obs})}$ is representative of a depth average. The vertical distribution of Chl $a$ was continuously measured during periods in September and October, and it was found that the depthresolved, 24-h-averaged Chl $a$ was nearly vertically uniform, suggesting that the comparison between the 24$\mathrm{h}$-averaged point measurement and the depth-integrated model is valid.

NP model-data comparison-The NP model performance was investigated with the linear uptake function $\mu_{V}$ (Eq. 12) over a range of $V$ and $m$ parameters, and quantified with

$$
\text { skill }=1-\left\langle\left(\mathrm{Chl} a^{(m)}-\mathrm{Chl} a^{(\mathrm{obs})}\right)^{2}\right\rangle /\left\langle\mathrm{Chl} a^{(\mathrm{obs})}\right\rangle^{2}
$$

(where $<>$ represent a time average of the 4-month record) and correlation $r^{2}$ (contours and colors in Fig. 10, respectively). Here, the skill represents the least-squares fit between the model and data, with skill $=1$ corresponding to a perfect match, and skill $=0$ corresponding to $\mathrm{Chl}$ $a^{(\mathrm{m})}=0$. The NP model skill and $r^{2}$ both have a single ridge over narrow $V$ and $m$ ranges (Fig. 10), tilted so that a larger loss $m$ is compensated by increased uptake $V$, i.e., the expected trade-off between growth and losses. The skill and $r^{2}$ maxima overlap at $V=0.52 \mathrm{~m}^{3} \mathrm{~d}^{-1} \mathrm{mmol}^{-1}$ (hence the choice of $V$ in Fig. 9) and $m=0.55 \mathrm{~d}^{-1}$ (see asterisk in Fig. 10) at $r^{2}=0.49$ and the skill of 0.61 . The mean $\mathrm{NO}_{3, T}$ $=0.73 \mathrm{mmol} \mathrm{m}-3$ yields (from Eq. 12) a mean growth rate $\mu=0.38 \mathrm{~d}^{-1}$.

The growth $V$ and loss $m$ parameters represent bulk averages of more complex, time-varying processes. However, the parameters that are obtained through optimizing the model-data fit are similar to those obtained through laboratory and process studies. Under low nutrient conditions $\left(<2 \mu \mathrm{mol} \mathrm{L}^{-1}\right)$, phytoplankton growth rates $(\mu)$ tend to range between 0.1 to $1 \mathrm{~d}^{-1}$ (Eppley et al. 1969), implying a $V$ between 0.05 and $2 \mathrm{~m}^{3} \mathrm{~d}^{-1} \mathrm{mmol}^{-1}$. Loss $m$ may occur through predation, cell lysis, advection, or sinking from the euphotic zone. For example, in nutrient-depleted 

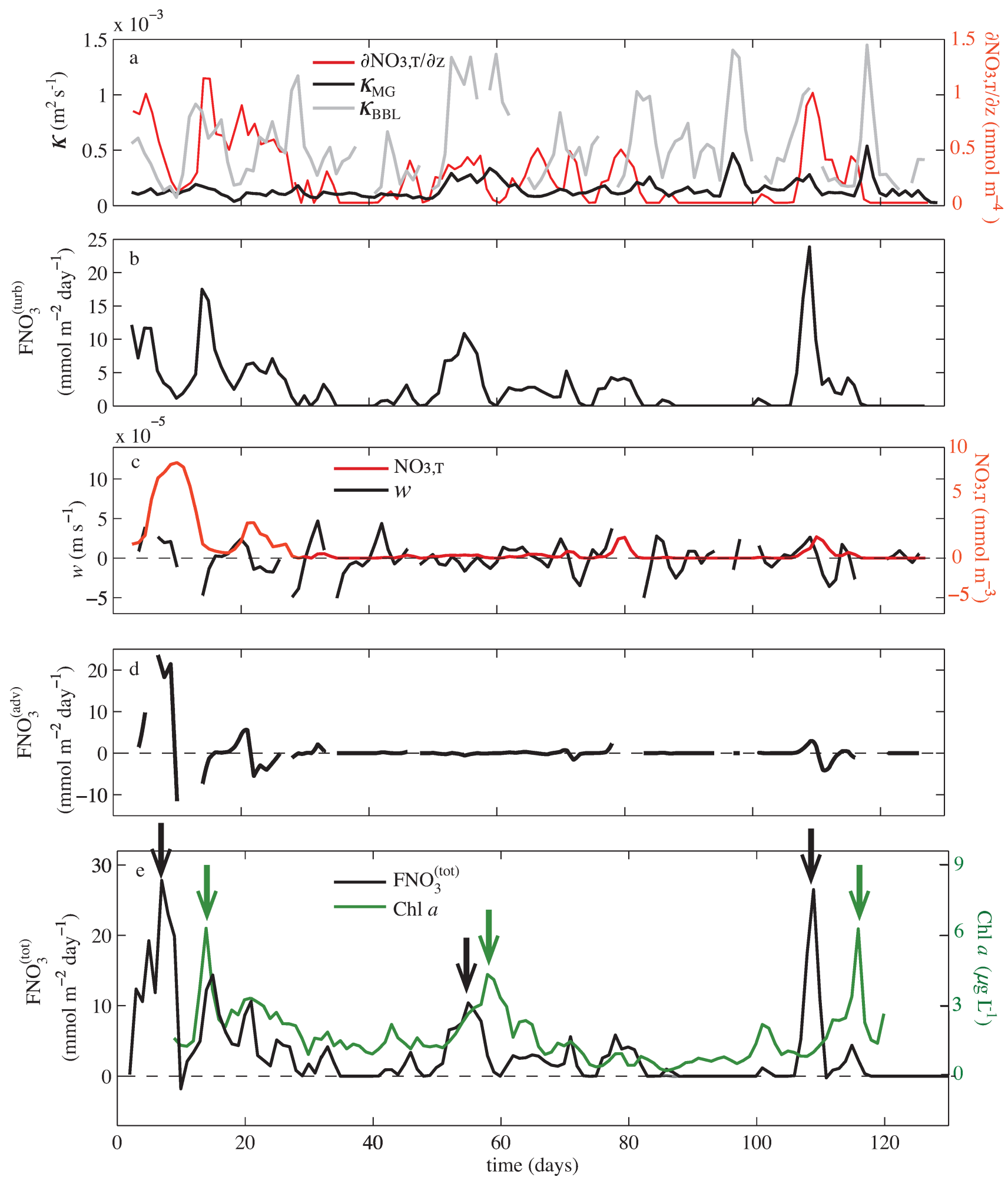

Fig. 8. 24-h-averaged time series of (a) vertical eddy diffusivity $\kappa\left(\mathrm{m}^{2} \mathrm{~s}^{-1}\right)$ estimated from the Mackinnon and Gregg (2005) parameterization $\left(\kappa_{\mathrm{MG}}\right.$, black line) and the $\mathrm{BBL}$ method $\left(\kappa_{\mathrm{BBL}}\right.$, gray line) and vertical $\mathrm{NO}_{3}$ gradient $\partial \mathrm{NO}_{3, T} / \partial z\left(\mathrm{red}\right.$ line, mmol m$\left.{ }^{-4}\right)$. The two $\kappa$ parameterizations are significantly linearly correlated, with $r^{2}=0.65$ and $p<0.001$. (b) Turbulent vertical nitrate flux FNO ${ }_{3}^{\text {(turb) }}$ (Eq. 1) estimated using $\kappa_{M G}$. (c) Vertical isotherm displacement rate $w$ (black line), $\mathrm{NO}_{3, T}$ (red line), and (d) advective vertical nitrate flux $\mathrm{FNO}_{3}^{\text {(adv) }}$ (Eq. 7). (e) Total vertical nitrate flux $\mathrm{FNO}_{3}^{\text {(tot) }}$ (black line) and Chl $a$ (green line). The observed Chl $a$ and FNO ${ }_{3}^{\text {(tot) }}$ have maximum lagged correlation $\left(r^{2}=0.40\right)$ at $8 \mathrm{~d}$ (approximately the separation of the vertical arrows at local $\mathrm{NO}_{3}$ maxima). All variables (except $\mathrm{Chl} a$ ) and flux estimates are estimated at $z_{e u}=-14 \mathrm{~m}$ from mooring M18. 


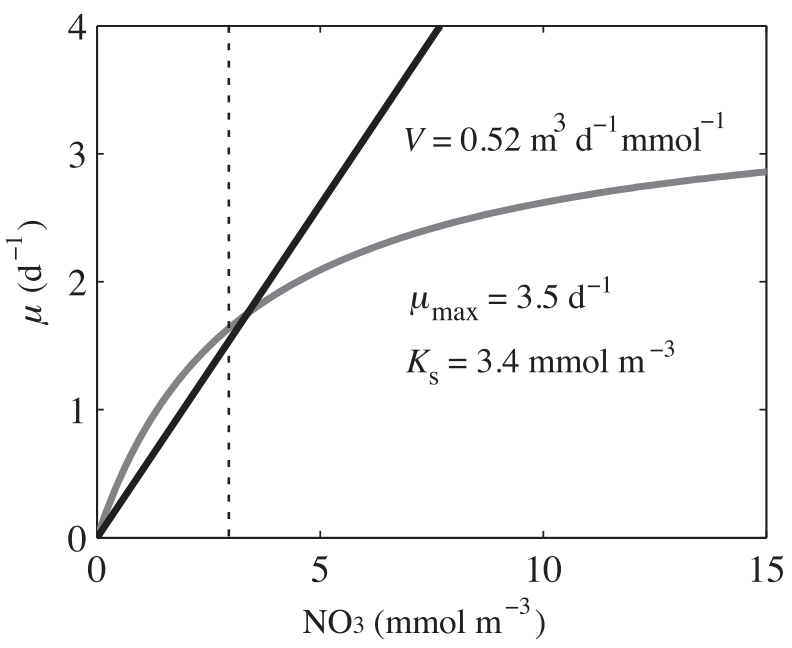

Fig. 9. Growth rate $\left(\mu, \mathrm{d}^{-1}\right)$ vs. $\mathrm{NO}_{3}\left(\mathrm{mmol} \mathrm{m}^{-3}\right)$ for linear uptake $\left(V=0.52 \mathrm{~m}^{3} \mathrm{~d}^{-1} \mathrm{mmol}^{-1}\right.$, black line) and a Monod function $\left(\mu_{\max }=3.5 \mathrm{~d}^{-1}, K_{\mathrm{s}}=3.4 \mathrm{mmol} \mathrm{m} \mathrm{m}^{-3}\right.$, gray line). The nonzero observed $\mathrm{NO}_{3, T}<K_{\mathrm{S}} 89 \%$ of the time (dashed vertical line), indicating that for the majority of the observed $\mathrm{NO}_{3}$ concentrations (and according to these parameter choices), the Monod curve was roughly linear.

conditions, many dinoflagellates form cysts (Pena-Manjarreza et al. 2005), swimming in cultures of $L$. polyedrum weakens, and cells sink at $\approx 6 \mathrm{~m} \mathrm{~d}^{-1}$ (Holmes et al. 1967). Where the euphotic depth $z_{\text {eu }}=-14 \mathrm{~m}$, a sinking-dependent loss $\left(m_{\text {sink }}=-w_{\text {sink }} / z_{\text {eu }}\right)$ would be $0.37 \mathrm{~d}^{-1}$, similar to the model fit estimated $m=0.55 \mathrm{~d}^{-1}$.

Using the linear $\mu_{V}$ and the best-fit $V$ and $m$, the timing, magnitude, and duration of the three observed blooms are at least reproduced qualitatively by the model (skill $=0.61$, $r^{2}=0.49$, compare thin and thick green curves in Fig. 11a). For bloom 1, the $\mathrm{Chl} a^{(\mathrm{m})}$ peak overpredicts the observed Chl $a^{\text {(obs) }}$ by approximately $50 \%$ and the timing of the model peak is a little early. The model reproduces the $\sim 15$ d duration of bloom 1. For blooms 2 and 3, the model reproduces magnitude and timing of the $\mathrm{Chl} a^{\text {(obs) }}$ peaks, as well as the Chl $a^{\text {(obs) }}$ reduction as the bloom decays. Overall, the model reproduces a statistically significant fraction of the Chl $a$ variation during three independent bloom events driven only by temperature and current observations, indicating that the fundamental processes governing phytoplankton dynamics are captured.

\section{Discussion}

Phytoplankton research has long aimed to predict the timing and location of episodic blooms, particularly HABs that have negative effects on the local economy or ecosystem. Though nitrate is widely believed to control phytoplankton growth, the lack of correlation between monthly averaged temperature (a proxy for nitrate) and Chl $a$ (Kim et al. 2009) suggests either that phytoplankton respond nonlinearly, or that monthly averages may not sufficiently resolve the bloom dynamics. Here, we demonstrated that each of the three episodic blooms was preceded by a peak in the vertical nitrate flux $6-10 \mathrm{~d}$ earlier. These

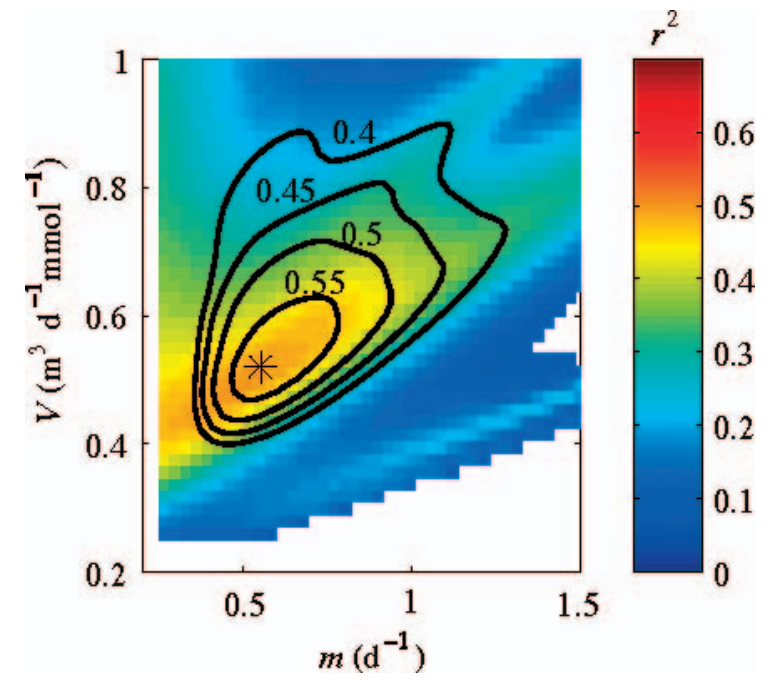

Fig. 10. Correlation coefficient ( $r^{2}$, colors) and model-data skill (contours) between $\mathrm{Chl} a^{(\mathrm{m})}$ and $\mathrm{Chl} a^{(\mathrm{obs})}$ over a range of the linear uptake parameter $\left(V, \mathrm{~m}^{3} \mathrm{mmol}^{-1} \mathrm{~d}^{-1}\right)$ and loss rate $(m$, $\mathrm{d}^{-1}$ ). The asterisk indicates the optimal choice of $V=$ $0.52 \mathrm{~m}^{3} \mathrm{mmol}^{-1} \mathrm{~d}^{-1}$ and $m=0.55 \mathrm{~d}^{-1}$ based upon the maximum correlation $\left(r^{2}=0.49, p<0.001\right)$ and skill $(0.61)$.

observations required vertically resolved gradients of temperature and currents, sufficiently rapid sampling to average out advection by the internal tide, and measurements over a long enough duration to statistically resolve the time lag between the flux and bloom events $(\sim 8 \mathrm{~d})$. Previous studies have found that advected $\mathrm{NO}_{3}$ flux, through either upwelling (Eppley et al. 1979) or tilted isotherms (Lucas et al. 2011), is important for sustaining the high coastal and nearshore productivity in southern California. The analysis presented here indicates that, depending on the nitracline depth, turbulent $\mathrm{NO}_{3}$ flux (either through BBL or IW breaking) was an important driver of the summer and fall blooms.

Mechanisms underlying the episodic nutrient flux eventsThe vertical $\mathrm{NO}_{3}$ flux events preceding the blooms were associated with vertical advection and turbulent mixing, characterized by shoaling isotherms and enhanced watercolumn shear, respectively. The diverse and co-occurring forcing mechanisms, to be presented in detail elsewhere, are discussed briefly here. The fraction of shear variance contained in the subtidal $(f<0.72 \mathrm{cpd})$, diurnal/inertial $(0.84<f<1.2 \mathrm{cpd})$, and semidiurnal $(1.6<f<4.8 \mathrm{cpd})$ bands was estimated at $z=-14 \mathrm{~m}$ (where $\mathrm{NO}_{3}$ flux was estimated) as a function of time with Fourier analysis of a sliding 7-d window. The inertial $(1.1 \mathrm{cpd})$ and diurnal (1 cpd) band frequencies are similar, and are not separated.

Bloom 1 (shear-driven turbulence and advection): The episodic $\mathrm{NO}_{3}$ flux that preceded bloom 1 was associated with both shear-induced vertical mixing (Fig. 8b) and shoaling of cold $\left(<14.5^{\circ} \mathrm{C}\right)$, nutrient-rich water into the euphotic zone (Figs. 4a,c, 8d). During this period, subtidal processes dominated $(>60 \%)$ both the shear at $z=-14 \mathrm{~m}$ (indicative of BBL generated turbulence; Grant et al. 1984) and the isotherm shoaling (leading to the $\mathrm{NO}_{3}$ advective 


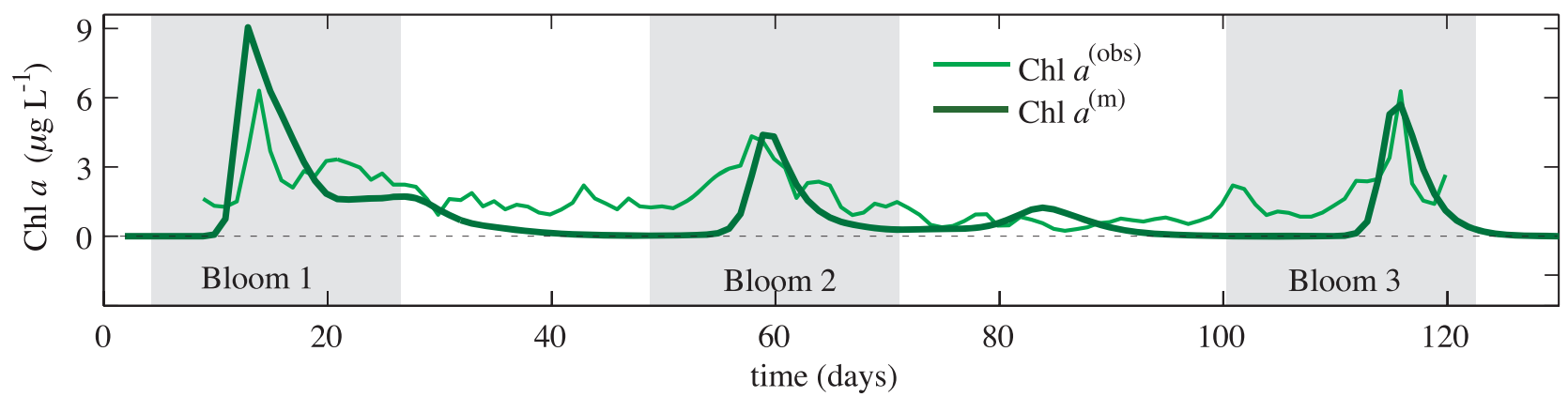

Fig. 11. Time series of 24-h averaged 15-m depth observed (Chl $a^{(\mathrm{obs})}$, light green line) and modeled (Chl $a^{(\mathrm{m})}$, dark green line) Chl $a$. The gray shaded regions indicate the time periods of the three bloom events.

flux and vertical gradient). Subtidal modulations of the pycnocline depth have previously been observed in the Southern California Bight (Kim et al. 2009), and may be caused by upwelling/relaxation (Huyer 1983; Denman and Powell 1984; Traganza et al. 1987), eddies (Bassin et al. 2005), propagating fronts (Washburn et al. 2011), or CTWs (Chavez 1996; Pringle and Riser 2003). The alongshore winds preceding and during the cooling event were not primarily southward, as required for classic wind-driven upwelling. Instead, a northward propagating cold-water signal was observed at five along-coast Southern California Coastal Ocean Observing Stations spanning from San Diego to Santa Barbara, with Huntington Beach lagging San Diego by approximately $4 \mathrm{~d}$ (not shown). The $\sim 0.7 \mathrm{~m} \mathrm{~s}^{-1}$ phase speed is consistent with a propagating CTW (Pringle and Riser 2003) but somewhat faster than expected for a sub-mesoscale eddy (Bassin et al. 2005).

Blooms 2 and 3 (shear-driven turbulence): Blooms 2 and 3 were preceded by enhanced shear, leading to elevated estimates of vertical mixing and thereby $\mathrm{NO}_{3}$ flux. The bloom 2 and 3 turbulent $\mathrm{NO}_{3}$ flux events centered on days 60 and 110 (Fig. 8c) corresponded to shear in the diurnal band that was larger than or equal to the subtidal shear and larger than the semidiurnal shear. Diurnal shear may be forced by the diurnal internal tide (Nam and Send 2011) or externally, i.e., by the diurnal wind. The strongly diurnal cross-shore wind and the surface currents were phase locked during these two periods, but were not significantly in phase for rest of the record. These observations are consistent with previous Southern California Bight observations, where under particular larger-scale vorticity conditions, the diurnal sea-land breeze led to resonant diurnal-band baroclinic motions (Lerczak et al. 2001), resulting in enhanced shear. Bloom 2 and $3 \mathrm{NO}_{3}$ flux events may have been driven by a similar mechanism.

Variability in Chl a due to changing growth rate, loss rate, life history, and motility of the phytoplankton communityThe 24-h averaged estimated vertical $\mathrm{NO}_{3}$ flux and measured Chl $a$ were significantly correlated $\left(r^{2} \approx 0.40\right)$ with a time lag between 6 and $10 \mathrm{~d}$. The net growth rate $(\mu-m)$, inferred from model parameters (such as $\mu_{\max }, K_{\mathrm{s}}$, $V$, and $m$ ), represents a bulk average that encompasses complex life histories and interactions among organisms.
Approximately half of the Chl $a$ variability in the 4-month record was explained by a very simple two-parameter NP model driven by the sum of the estimated turbulent and advective vertical $\mathrm{NO}_{3}$ flux. The remaining variability is likely due both to factors that were not included in the model and to errors in the bulk model parameters, as discussed in the following sections.

The succession of early summer diatom dominance with a shift to dinoflagellate dominance during the fall has been observed previously near Huntington Beach (Briand 1976). A shift in community composition will change the community net growth rate. For example, diatoms generally have lower $K_{\mathrm{s}}$ than dinoflagellates (Eppley et al. 1969), resulting in larger $\mu$ in diatom-dominated blooms relative to dinoflagellate-dominated blooms.

During the growth stage of each bloom, the net growth rate $(\mu-m)$ was inferred directly from logarithmic fits of measured Chl $a$ (Fig. 1). The net growth rate was highest during bloom $1\left(0.57 \mathrm{~d}^{-1}\right)$ and lower during blooms 2 $\left(0.17 \mathrm{~d}^{-1}\right)$ and $3\left(0.22 \mathrm{~d}^{-1}\right)$. Although the community composition of blooms 1 and 2 is not known, previous observations (Briand 1976) suggest bloom 1 was diatom dominated, consistent with the higher observed net growth rate relative to the known (L. polyedrum) dinoflagellatedominated bloom 3 .

Motile dinoflagellates (which represent $\sim 75 \%$ of $\mathrm{HAB}$ species) are particularly challenging to model with a simple nutrient-dependent growth function. These species possess complex life histories and unique physiological characteristics that may encourage the rapid formation of dense blooms (Smayda 1997). For example, during nutrientdepleted conditions, many dinoflagellates form negatively buoyant cysts that remain dormant on the seafloor until environmental conditions improve (Pena-Manjarreza et al. 2005). Motility may allow the organisms to experience enhanced light exposure or access to deep nutrient pools, and many dinoflagellates produce allelochemicals and toxins that may enhance survival by inhibiting intraspecific competition (Guisande et al. 2002) and grazers (Huntley 1982), implying a density-dependent mortality. These traits encourage the ephemeral, often rapid, and opportunistic growth response, dense cell concentrations, and sudden declines that characterize red tides. These complex factors will give rise to $\mathrm{Chl} a$ variability that cannot be represented in the simple NP model framework. 
The role of new production $v$ s. recycled production-The sole input in the simple NP model was the vertical flux of new $\mathrm{NO}_{3}$ into the euphotic zone. Therefore, Chl $a^{(\mathrm{m})}$ reflects the new production of biomass (Dugdale and Goering 1967). However, the measured $\mathrm{Chl} a^{\text {(obs) }}$ reflects the total production (new plus recycled). The recycled production is expected to vary as the euphotic nitrogen sources (phytoplankton and predator community and abundance) change with time. Bloom events in Southern California are often fueled by inputs of new $\mathrm{NO}_{3}$ into the euphotic zone (Horner et al. 1997). Therefore, during the growth phase of the three blooms, $\mathrm{Chl} a^{(\mathrm{m})}$ is expected to be an appropriate representation of $\mathrm{Chl} a^{(\mathrm{obs})}$. During bloom decline phases or non-bloom periods, $\mathrm{Chl} a^{(\mathrm{obs})}$ is elevated above Chl $a^{(\mathrm{m})}$ (Fig. 11), consistent with the presence of (unmodeled) nutrient recycling. This mismatch between Chl $a^{(\mathrm{m})}$ and $\mathrm{Chl} a^{\text {(obs) }}$ may also have occurred because the growth and loss terms within the model represent primarily those of the large diatom and dinoflagellate cells that may rapidly respond to large nutrient inputs. A different population of cells may contribute to low, elevated Chl $a^{\text {(obs) }}$ between these blooms. Similar, low background Chl $a$ is also often present in long-term field records (Scripps Institution of Oceanography pier Chl $a$, SCCOOS.org).

Advection-induced Chl a variability - The model assumes that the euphotic Chl $a$ is spatially uniform. The validity of this assumption was assessed by estimating the magnitude of the advective terms from the cross-shore CTD + Chl $a$ transects and wirewalker and satellite-derived Chl $a$ observations, and comparing these to the typical $\partial \mathrm{Chl}$ $a / \partial t$ during the development of the blooms, which ranged from 0.5 (bloom 2) to $1.5 \mu \mathrm{g} \mathrm{L}^{-1} \mathrm{~d}^{-1}$ (bloom 1).

The Chl $a$ vertical advection term $(w \partial \mathrm{Chl} a / \partial \mathrm{z})$ was estimated from the vertical $\mathrm{Chl} a$ gradient and the isotherm vertical displacement rate $(w)$ during the rapidly profiling wirewalker deployment between 17 September and 18 October. The vertical Chl $a$ gradient was calculated between $z=-7 \mathrm{~m}$ and $z=-13 \mathrm{~m}$, and $w$ was calculated at $-10 \mathrm{~m}$. Both $\partial \mathrm{Chl} a / \partial z$ and $w$ were dominated by diurnal and semidiurnal variability as the $\mathrm{Chl} a$ and isotherms were advected by the internal tide. The maximum $24-\mathrm{h}$ averaged $w \partial \mathrm{Chl} a / \partial z$ was only $0.1 \mu \mathrm{g} \mathrm{L}^{-1} \mathrm{~d}^{-1}$ (on 12 October) and the mean during the wirewalker deployment was $0.001 \mu \mathrm{g} \mathrm{L}^{-1} \mathrm{~d}^{-1}$ (with root mean square [rms] = $\left.0.27 \mu \mathrm{g} \mathrm{L}^{-1} \mathrm{~d}^{-1}\right)$. This vertical advection of Chl $a$ was smaller than the observed $\partial \mathrm{Chl}$ a/ $\partial \mathrm{t}$ ( 0.5 to $\left.1.5 \mu \mathrm{g} \mathrm{L}^{-1} \mathrm{~d}^{-1}\right)$, indicating that the rapid and persistent increase in $\mathrm{Chl} a$ associated with the three bloom events was not driven by vertical advection of Chl $a$ gradients.

The hourly averaged cross-shore velocities within a few kilometers of the shore were small $\left(<0.05 \mathrm{~m} \mathrm{~s}^{-1}\right)$ and forced by the diurnal sea breeze and internal tide. Detailed analysis of the cross-shore CTD + Chl $a$ transects conducted preceding and during bloom 3 demonstrated that cross-shore Chl $a$ advection was not responsible for the increase in Chl $a$ (Omand et al. 2011). The net 24-h crossshore transport distances estimated from the integrated cross-shore currents were so small that despite the sometimes strong cross-shore gradients in $\mathrm{Chl} a$, the effect of cross-shore Chl $a$ advection was near zero.

The role of alongshore advection ( $v \partial \mathrm{Chl} a / \partial y$ ) was assessed only qualitatively with satellite $\mathrm{Chl} a$, because of known effects of nearshore bottom reflection, albedo, aerosols, and turbidity on remotely sensed $\mathrm{Chl} a$, and potentially large gradients in subsurface Chl $a$ (Zibordia et al. 2009). Despite these issues, the daily satellite-derived (4$\mathrm{km}$ resolution, moderate resolution imaging spectroradiometer [MODIS] level 3) spatially averaged (over a $12 \mathrm{~km}$ by $12 \mathrm{~km}$ region centered at the HB06 site) Chl $a$ was significantly correlated with the in situ Chl $a$ during blooms 1 and 3 ( $r^{2}=0.48, p<0.001$, black points in Fig. 12). This result demonstrates that for at least two of the blooms, the variation in a point measurement at $15-\mathrm{m}$ depth was similar to the near-surface Chl $a$ variability spatially averaged over $144 \mathrm{~km}^{2}$, and indicates that the blooms had a relatively large spatial extent. However, intense subsurface $\mathrm{Chl} a$ may not be adequately detected by the satellite. Although the correlation was high, the satellite $\mathrm{Chl} a$ was a factor of 4.1 less than Chl $a^{\text {(obs) }}$ during blooms 1 and 3 (dashed line, Fig. 12), and during bloom 2 it was not correlated (gray points, Fig. 12). During bloom 2, the surface to bottom temperature difference was largest (see days 50-70, Fig. 4a), indicating that the Chl $a$ measured at $15 \mathrm{~m}$ below the surface may have been retained near the bottom by a density barrier, potentially undetected by satellite. The horizontal gradients obtained from the satellite $\mathrm{Chl} a$ are therefore multiplied by 4.1 , and used to generate a conservative guess for the potential variability in the subsurface alongshore advection. The alongshore currents during the 4-month period were predominantly towards the south, and satellite-derived gradients in $\partial \mathrm{Chl} a / \partial \mathrm{y}$ were explored over a range spanning 4-100 km to the north of the instrument array. The maximum transport distance over $4 \mathrm{~d}$ (the shortest growth phase, during bloom 1, see Fig. 1), was approximately $30 \mathrm{~km}$ towards the south, and the mean of the absolute magnitude change in $\mathrm{Chl} a$ over this distance was $1.7 \mu \mathrm{g} \mathrm{L}^{-1}$ (multiplied by the 4.1 scale factor) with $\mathrm{rms}=8.8 \times 10^{-2} \mu \mathrm{g} \mathrm{L}^{-1}$. Therefore, maximum alongshore advection sustained (over $4 \mathrm{~d}$ ) $v \partial \mathrm{Chl}$ a/ $\partial \mathrm{y}$ was $0.43 \mu \mathrm{g} \mathrm{L}^{-1} \mathrm{~d}^{-1}$, which is smaller than $\partial \mathrm{Chl} a / \partial \mathrm{t}$ for all three of the blooms, and implies that alongshore advection did not drive the observed $\mathrm{Chl} a^{\text {(obs) }}$ variability.

Recommendations - Estimation of vertical $\mathrm{NO}_{3}$ flux into the euphotic zone requires knowledge of $\mathrm{NO}_{3}$ near $z_{e u}$. In some cases where the $\mathrm{NO}_{3}-T$ relationship is stable, $T$ may be used as a proxy for $\mathrm{NO}_{3}$. However, this approach should be used with caution. Short-timescale deviations in this relationship occur as $z_{\text {eu }}$, nitracline depth, $\mathrm{NO}_{3}$ uptake rates, or mixing intensity vary. Here, the observed variation in the $\mathrm{NO}_{3}-T$ relationship was small, and would affect the advected flux estimate by $<10 \%$. However, as direct measurements of $\mathrm{NO}_{3}$, together with temperature (or density) measurements, become more abundant, this relationship should be further assessed for its stability over the timescales of mixing and advection events and phytoplankton uptake responses. 


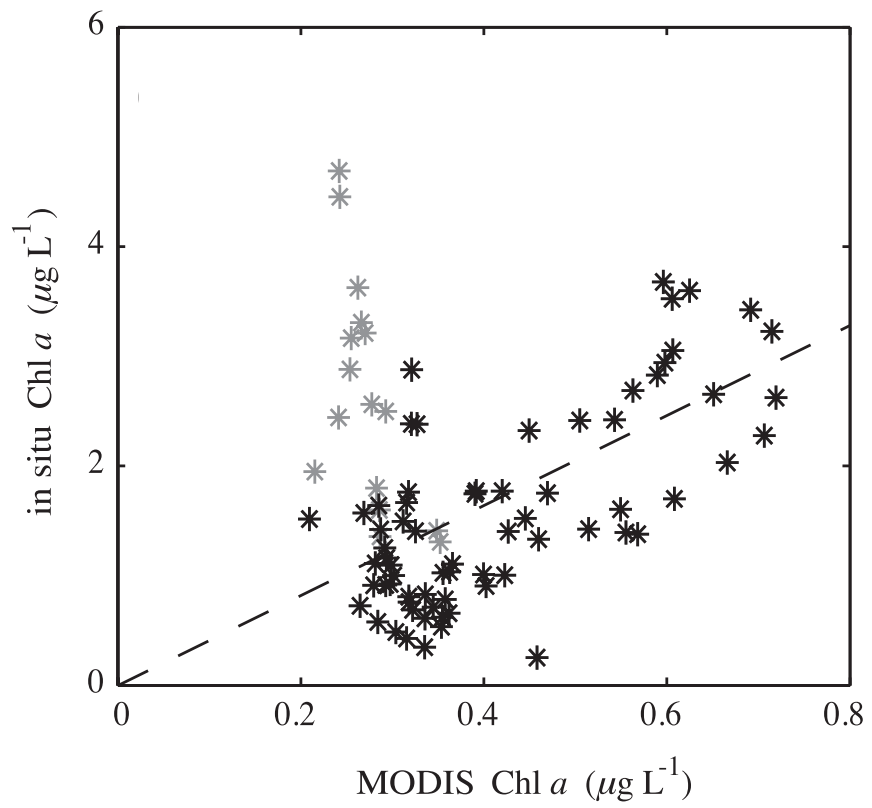

Fig. 12. 24-h averaged subsurface Chl $a$ vs. MODIS Chl $a$ averaged over a 12 by $12-\mathrm{km}$ region centered at the study site (asterisks). The dashed line indicates the linear fit (slope $=4.1$ ) between Chl $a^{\text {(obs) }}$ and MODIS Chl $a(n=96$, black asterisks), excluding those from a 16-d period during bloom $2(n=16$, gray asterisks).

Direct measurement of the TKE dissipation rate $\varepsilon$ or tracer flux could significantly improve the parameterizations of $\kappa$ presented here. Estimating turbulent $\mathrm{NO}_{3}$ flux across $z_{e u}$ is particularly complex in the nearshore, where $z_{e u}$ may span the BBL and stratified mid-water column. Here, we found that $\kappa$ estimated from both the BBL and IW parameterizations was correlated and strongly controlled by shear, indicating that in the absence of direct estimates of flux or dissipation, background shear is a useful starting point for understanding the intermittent (days-weeks) temporal variability in nearshore turbulence. Lastly, in addition to a time-dependent estimate of $\kappa$, it is also necessary to know the $\mathrm{NO}_{3}$ gradient across $z_{e u}$. A period of enhanced $\kappa$ will have no effect on the flux if the nitracline is deeper than $\mathrm{z}_{e u}$ and the gradient $\partial \mathrm{NO}_{3} / \partial \mathrm{z}$ is weak (for example, see days 95-100, Fig. 8a).

\section{Significance to aquatic environments}

Chl $a$ was measured in $\sim 15-\mathrm{m}$ water depth near Huntington Beach, California, from summer to fall (JuneOctober) 2006. Three distinct Chl $a$ blooms (with 24-haveraged $\mathrm{Chl} a>3 \mu \mathrm{g} \mathrm{L}^{-1}$ ) were observed, each lasting for approximately 1-2 weeks. Nitrate measurements obtained during 1 month were used to develop a temperature proxy for $\mathrm{NO}_{3}$. The proxy was used to estimate the vertical flux of $\mathrm{NO}_{3}$ into the euphotic zone, decomposed into two components: the advective and turbulent fluxes. The advective flux was estimated from the vertical isotherm displacements and the temperature-derived nitrate. The turbulent vertical $\mathrm{NO}_{3}$ flux used a $\mathrm{NO}_{3}$ diffusivity $\kappa$ that was derived from both IW-based and logarithmic BBLbased parameterizations. Each $\kappa$ parameterization uses simplifying assumptions. However, over subtidal time scales, the $\kappa$ estimates were correlated, and had similar dependence on the vertical shear of horizontal currents. The resulting turbulent $\mathrm{NO}_{3}$ flux estimate (based on the temperature-derived vertical $\mathrm{NO}_{3}$ gradient) was elevated preceding the three bloom time periods. The total flux had roughly equal contributions from advection and turbulent flux prior to the first bloom event, but was dominated by the turbulent flux at later times (blooms 2 and 3). The maximum squared correlation $\left(r^{2}=0.40\right)$ between Chl $a$ and the total $\mathrm{NO}_{3}$ flux occurred with $\mathrm{Chl} a$ lagging the $\mathrm{NO}_{3}$ flux by $6-10 \mathrm{~d}$, consistent with a growth response of the phytoplankton to $\mathrm{NO}_{3}$ availability.

The estimated $\mathrm{NO}_{3}$ flux was used to drive a simple NP model. During the blooms, vertical and horizontal advection of Chl $a$ were found to be small relative to the Chl $a$ time derivative, and were not included in the model. In addition, for the low range of observed $\mathrm{NO}_{3}$, a Monod growth rate was roughly linear, allowing the use of a linear uptake function. Thus, the NP model has two parameters, growth rate $V$ and morality rate $m$, that were explored. The model has maximum skill (and correlation) for $m=$ $0.55 \mathrm{~d}^{-1}$ and $V=0.52 \mathrm{~m}^{3} \mathrm{~d}^{-1} \mathrm{mmol}^{-1}$. With these parameters, the approximate timing, duration, and magnitude of the three observed $\mathrm{Chl} a$ blooms were reproduced. The success of a very simple two-parameter NP model in reproducing the fundamental features of all three blooms (when both the advective and turbulent $\mathrm{NO}_{3}$ fluxes are included) highlights the strong connection between the vertical nitrate flux and the lagged $\mathrm{Chl} a$ response, and may assist the design of future nearshore programs in identifying the critical physical parameters and timescales to gain a potentially predictive insight into bloom dynamics in Southern California.

\section{Acknowledgments}

These observations were obtained within the framework of the larger Southern California Coastal Ocean Observing System (SCCOOS) and United States Geological Survey (USGS) programs at Huntington Beach. We thank Burt Jones and Ivona Cetinic for the use of the moored chlorophyll $a$ fluorometer data (Chl $a^{\text {(obs) })}$. Thank you to Ali Boehm and Simon Wong for the Acoustic Doppler Current Profiler data in 18-m depth (M18). Thank you to George Robertson and Marlene Noble for the moored instrument data. We thank Jim Leichter for field assistance and providing the Seabird conductivity, temperature, depth, chlorophyll $a$, and $\mathrm{NO}_{3}$ profiles, and Andrew Lucas for the wirewalker data. B. Woodward, B. Boyd, K. Smith, D. Darnell, I. Nagy, D. Clark, M. Rippy, M. McKenna, M. Yates, and D. Michrowski provided field support. Uwe Send and Steve Weisberg are thanked for their cooperation and assistance. Thank you to two anonymous reviewers for providing recommendations that improved the manuscript. California Sea Grant, National Oceanic and Atmospheric Administration, California Coastal Conservancy, National Science Foundation, and the Office of Naval Research supported this research. Sea Grant support was through the California Sea Grant College Program Project R/CZ-196, through National Ocean and Atmospheric Administration's National Sea Grant College Program, U.S. Dept. of Commerce. 


\section{References}

Agrawal, Y. C., AND Others. 1992. Enhanced dissipation of kinetic-energy beneath surface-waves. Nature 359: 219-220, doi: $10.1038 / 359219 \mathrm{a} 0$

Anderson, D. 1997. Turning back the harmful red tide. Nature 388: 513-514, doi:10.1038/41415

Anderson, D. M., AND others. 2008. Harmful algal blooms and eutrophication: Examining linkages from selected coastal regions of the United States. Harmful Algae 8: 39-53, doi:10.1016/j.hal.2008.08.017

Bassin, C. J., L. Washburn, M. Brzezinski, and E. McPheeSHAw. 2005. Sub-mesoscale coastal eddies observed by high frequency radar: A new mechanism for delivering nutrients to kelp forests in the Southern California Bight. J. Geophys. Res. 32: L12604, doi:10.1029/2005GL023017

Behrenfeld, M. J., E. Boss, D. A. Siegel, and D. M. Shea. 2005. Carbon-based ocean productivity and phytoplankton physiology from space. Global Biogeochem. Cycles 19: GB1006, doi:10.1029/2004GB002299

BRIAND, F. 1976. Seasonal variations and associations of Southern Californian nearshore phytoplankton. J. Ecol. 64: 821835.

Chavez, F. P. 1996. Forcing and biological impact of onset of the 1992 El Nino in Central California. Geophys. Res. Lett. 23: 265-268, doi:10.1029/96GL00017

Cloern, J., C. Grenz, and L. Vidergar-Lucas. 1995. An empirical model of the phytoplankton chlorophyll:carbon ratio- the conversion factor between productivity and growth rate. Limnol. Oceangr. 40: 1313-1321, doi:10.4319/ 10.1995.40.7.1313

Csanady, G. T. 1984. The free surface turbulent shear layer. J. Phys. Oceanogr. 14: 402-411, doi:10.1175/1520-0485 (1984)014<0402:TFSTSL $>2.0$. CO;2

Cullen, J., E. Stewart, R. Renger, and C. Winant. 1983. Vertical motion of the thermocline, nitracline and chlorophyll maximum layers in relation to currents on the Southern California shelf. J. Mar. Res. 41: 239-262, doi:10.1357/ 002224083788520171

Denman, K. L., And T. M. Powell. 1984. Effects of physical processes on planktonic ecosystems in the coastal ocean. Oceanogr. Mar. Biol. Annu. Rev. 22: 125-168.

Dewey, R. K., And W. R. Crawford. 1987. A microstructure instrument for profiling oceanic turbulence in coastal bottom boundary layers. J. Atmos. Ocean. Tech. 4: 288-297, doi:10.1175/1520-0426(1987)004<0288:AMIFPO>2.0.CO;2

Dugdale, R., C. Davis, and F. Wilkerson. 1997. Assessment of new production at the upwelling center at Point Conception, California, using nitrate estimated from remotely sensed sea surface temperature. J. Geophys. Res. 102: 8573-8585, doi:10.1029/96JC02136

—, AND J. GoERING. 1967. Uptake of new and regenerated forms of nitrogen in primary productivity. Limnol. Oceangr. 12: 196-206, doi:10.4319/lo.1967.12.2.0196

Eppley, R., E. Renger, And W. Harrison. 1979. Nitrate and phytoplankton production in Southern California coastal waters. Limnol. Oceangr. 23: 483-494, doi:10.4319/ 10.1979.24.3.0483

Eppley, R. W., J. N. Rogers, and J. J. McCarthy. 1969. Halfsaturation constants for uptake of nitrate and ammonium by marine phytoplankton. Limnol. Oceangr. 14: 912-920, doi:10.4319/lo.1969.14.6.0912

Franks, P. J. S. 2009. Planktonic ecosystem models: Perplexing parameterizations and a failure to fail. J. Plankton Res. 31: 1299-1306, doi:10.1093/plankt/fbp069
Gargett, A., And J. Moum. 1995. Mixing efficiencies in turbulent tidal fronts: Results from direct and indirect measurements of density flux, J. Phys. Oceanogr. 25: 2583-2608, doi:10.1175/ 1520-0485(1995)025<2583:MEITTF > 2.0.CO;2

Grant, W., A. Williams, III, and S. M. Glenn. 1984. Bottom stress estimates and their prediction on the Northern California continental shelf during CODE-1: The importance of wave-current interaction. J. Phys. Oceanogr. 14: 506-527, doi:10.1175/1520-0485(1984)014<0506:BSEATP > 2.0.CO;2

Grant, W. D., and O. S. Madsen. 1979. Combined wave and current interaction with a rough bottom. J. Geophys. Res. 84: 1797-1808, doi:10.1029/JC084iC04p01797

GregG, M. 1989. Scaling turbulent dissipation in the thermocline. J. Geophys. Res. 94: 9686-9698, doi:10.1029/ JC094iC07p09686

Guisande, C., M. Frangpulos, I. Maneiro, A. Vergara, and I. RIVEIRO. 2002. Ecological advantages of toxin production by the dinoflagellate Alexandrium minutum under phosphorus limitation. Mar. Ecol. Prog. Ser. 225: 169-176, doi:10.3354/ meps 225169

Henyey, F., J. Wright, and S. Flatté. 1986. Energetics of borelike internal waves. J. Geophys. Res. 102: 3323-3330, doi:10.1029/96JC03558

Holmes, R. 1970. The secchi disk in turbid coastal waters. Limnol. Oceangr. 15: 688-694, doi:10.4319/1o.1970.15.5.0688

Holmes, R. W., P. M. Williams, and R. W. Eppley. 1967. Red water in La Jolla Bay, 1964-1966. Limnol. Oceangr. 12: 503-512, doi:10.4319/1o.1967.12.3.0503

Horner, R., D. Garrison, and F. Plumley. 1997. Harmful algal blooms and red tide problems on the U.S. West Coast. Limnol. Oceangr. 42: 1076-1088, doi:10.4319/1o.1997.42.5_ part_2.1076

Huntley, M. 1982. Yellow water in La Jolla Bay, California, July 1980. II. Suppression of zooplankton grazing. J. Exp. Mar. Biol. Ecol. 63: 81-91, doi:10.1016/0022-0981(82)90052-1

Huyer, A. 1983. Coastal upwelling in the California current system. Prog. Oceanogr. 12: 259-284, doi:10.1016/00796611(83)90010-1

Kim, H., A. Miller, J. McGowan, and M. Carter. 2009. Coastal phytoplankton blooms in the Southern California Bight. Prog. Oceanogr. 82: 137-147, doi:10.1016/j.pocean.2009.05. 002

Legand, K., And A. Thomas. 2007. Spatial patterns of intraseasonal variability of chlorophyll and sea surface temperature in the California Current. J. Geophys. Res. 112: C06032, doi:10.1029/2007JC004097

Lerczak, J., M. Hendershott, and C. Winant. 2001. Observations and modeling of coastal internal waves driven by a diurnal sea breeze. J. Geophys. Res. 106: 19715-19730, doi:10.1029/2001JC000811

LucAs, A. 2009. The physical control of phytoplankton dynamics over the Southern California Bight continental shelf. Ph.D. Thesis. Univ. of California San Diego.

Lucas, A. J., P. J. S. Franks, and C. Dupont. 2011. Horizontal internal-tide fluxes support elevated phytoplankton productivity over the inner continental shelf. Limnol. Oceangr: Fluids Environ. 1: 56-74, doi:10.1215/21573698-1258185

Mackinnon, J. A., And M. C. GRegG. 2003. Mixing on the latesummer New England Shelf-solibores, shear, and stratification. J. Phys. Oceanogr. 33: 1476-1492, doi:10.1175/15200485(2003)033<1476:MOTLNE > 2.0.CO;2

, AND —. 2005. Spring mixing: Turbulence and internal waves during restratification on the New England Shelf. J. Phys. Oceanogr. 35: 2425-2443, doi:10.1175/ JPO2821.1 
Nam, S., And U. Send. 2011. Direct evidence of deep-water intrusions onto the continental shelf via surging internal tides. J. Geophys. Res. 116: C05004, doi:10.1029/2010JC006692

Noble, M. A., B. Jones, P. Hamilton, J. Xu, G. Robertson, L. Rosenfeld, AND J. LARGIER. 2009. Cross-shore transport into nearshore waters due to shoaling internal tides in San Pedro Bay, CA. Cont. Shelf Res. 29: 1768-1785, doi:10.1016/ j.csr.2009.04.008

Olivieri, R., AND F. Chavez. 2009. A model of plankton dynamics for the coastal upwelling system of Monterey Bay, California. Deep-Sea Res. II 47: 1077-1106, doi:10.1016/S09670645(99)00137-X

Omand, M. M., J. J. Leichter, P. J. S. Franks, A. J. Lucas, R. T. Guza, and F. Feddersen. 2011. Physical and biological processes underlying the sudden appearance of a red-tide surface patch in the nearshore. Limnol. Oceangr. 56: 787-801, doi:10.4319/1o.2011.56.3.0787

Osborn, T. 1980. Estimates of the local rate of vertical diffusion from dissipation measurements. J. Phys. Oceanogr. 10: 83-89, doi:10.1175/1520-0485(1980)010<0083:EOTLRO > 2.0.CO;2

Parnell, P., E. Miller, C. Lennert-Cody, P. Dayton, M. Carter, and T. Stebinss. 2010. The response of giant kelp (Macrocystis pyrifera) in Southern California to low-frequency climate forcing. Limnol. Oceangr. 55: 2686-2702.

Parsons, T., P. Harrison, AND R. Waters. 1978. An experimental simulation of changes in diatom and dinoflagellate blooms. J. Exp. Mar. Biol. Ecol. 32: 285-294, doi:10.1016/00220981(78)90122-3

Pena-Manjarreza, J. L., J. Helenes, G. Gaxiola-Castroc, and E. Orellana-Cepeda. 2005. Dinoflagellate cysts and bloom events at Todos Santos Bay, Baja California, Mexico, 19992000. Cont. Shelf Res. 25: 1375-1393, doi:10.1016/ j.csr.2005.02.002

Pringle, J. M., And K. Riser. 2003. Remotely forced nearshore upwelling in Southern California. J. Geophys. Res. 108: 3131, doi:10.1029/2002JC001447

Rainville, L., AND R. Pinkel. 2001. Wirewalker: An autonomous wave-powered vertical profiler. J. Atmos. Ocean. Tech. 18: 1048-1051, doi:10.1175/1520-0426(2001)018<1048:WAAWPV> 2.0.CO;2

Redfield, A. 1958. The biological control of chemical factors in the environment. Am. Sci. 46: 206-226.

Santoro, A., N. Nidzieko, G. van Dijken, K. Arrigo, and A. Böнм. 2010. Contrasting spring and summer phytoplankton dynamics in the nearshore Southern California Bight. Limnol. Oceangr. 55: 264-278, doi:10.4319/1o.2010.55.1.0264
Sharples, J., C. M. Moore, and E. R. Abraham. 2001. Internal tide dissipation, mixing, and vertical nitrate flux at the shelf edge of NE New Zealand. J. Geophys. Res. 106: 14069-14081, doi:10.1029/2000JC000604

SHAw, W. 1999. Mechanisms of turbulent mixing in the continental shelf bottom boundary layer. Ph.D. Thesis, MIT and WHOI.

SmaydA, T. J. 1997. Harmful algal blooms: Their ecophysiology and general relevance to phytoplankton blooms in the sea. Limnol. Oceangr. 42: 1137-1153, doi:10.4319/lo.1997.42.5_ part_2.1137

SouzA, A. J., AND J. PinedA. 2001. Tidal mixing modulation of sea-surface temperature and diatom abundance in Southern California. Cont. Shelf Res. 21: 651-666, doi:10.1016/S02784343(00)00105-9

Tennekes, H., and J. L. Lumley. 1972. A first course in turbulence. MIT Press.

Traganza, E. D., D. G. Redalije, and R. W. Garwood. 1987. Chemical flux, mixed layer entrainment and phytoplankton blooms at upwelling fronts in the California coastal zone. Cont. Shelf Res. 7: 89-105, doi:10.1016/0278-4343(87)90066-5

UTERMÖHL, H. 1958. Zur Vervollkomnung der quantitativen Phytoplankton-Methodik. Mitteilungen der internationale Vereinigung für theoretische und angewandte. Limnologie 9: 1-38.

Washburn, L., M. R. Fewings, C. Melton, and C. Gotzchalk. 2011. The propagating response of coastal circulation due to wind relaxations along the central California coast. J. Geophys. Res. 116: C12028, doi:10.1029/2011JC007502

Wong, S., A. Santoro, N. J. Nidzieko, J. Hench, and A. B. Boenм. 2012. Coupled physical, chemical, and microbiological measurements suggest a connection between internal waves and surf zone water quality in the Southern California Bight. Cont. Shelf Res. 34: 64-78, doi:10.1016/j.csr.2011.12.005

Zibordia, G., J. Berthona, F. Melina, D. D'Alimonteb, and S. KaItAla. 2009. A validation of satellite ocean color primary products at optically complex coastal sites: Northern Adriatic Sea, Northern Baltic Proper and Gulf of Finland. Remote Sens. Environ. 13: 2574-2591.

Associate editor: Craig L. Stevens

Received: 12 October 2011 Accepted: 30 May 2012 Amended: 14 June 2012 